This pdf of your paper in Movement, Exchange and Identity in Europe in the 2nd and 1st Millennia $B C$ belongs to the publishers Oxbow Books and it is their copyright.

As author you are licenced to make up to 50 offprints from it, but beyond that you may not publish it on the World Wide Web until three years from publication (September 2020), unless the site is a limited access intranet (password protected). If you have queries about this please contact the editorial department at Oxbow Books (editorial@oxbowbooks.com). 


\section{MOVEMENT, EXCHANGE AND IDENTITY IN EUROPE IN THE 2ND AND 1ST MILLENNIA BC}




\title{
AN OFFPRINT FROM
}

\section{MOVEMENT, EXCHANGE AND IDENTITY IN EUROPE IN THE 2ND AND 1ST MILLENNIA BC}

\author{
BEYOND FRONTIERS
}

edited by

ANNE LEHOËRFF AND MARC TALON

Hardback Edition: ISBN 978-1-78570-716-2 (hardback)

Digital Edition: ISBN 978-1-78570-717-9 (epub) 
Published in the United Kingdom in 2017 by

OXBOW BOOKS

The Old Music Hall, 106-108 Cowley Road, Oxford OX4 1JE

and in the United States by

OXBOW BOOKS

1950 Lawrence Road, Havertown, PA 19083

(C) Oxbow Books and the individual authors 2017

Hardback Edition: ISBN 978-1-78570-716-2 (hardback)

Digital Edition: ISBN 978-1-78570-717-9 (epub)

A CIP record for this book is available from the British Library and the Library of Congress

All rights reserved. No part of this book may be reproduced or transmitted in any form or by any means, electronic or mechanical including photocopying, recording or by any information storage and retrieval system, without permission from the publisher in writing.

Printed in Malta by Melita Press

Typeset in India by Lapiz Digital Services, Chennai

For a complete list of Oxbow titles, please contact:

\section{UNITED KINGDOM}

Oxbow Books

Telephone (01865) 241249, Fax (01865) 794449

Email: oxbow@oxbowbooks.com

www.oxbowbooks.com

\section{UNITED STATES OF AMERICA}

Oxbow Books

Telephone (800) 791-9354, Fax (610) 853-9146

Email: queries@casemateacademic.com

www.casemateacademic.com/oxbow

Oxbow Books is part of the Casemate Group

Front cover: (C) Anne Lehoërff for BOAT 1550 BC. 


\section{Contents}

1. To think of leaving: mobility and identities in Western Europe during the Bronze Age Anne Lehoërff

2. On migrations: Sigfried Jan De Laet (1914-1999): his role in Belgian Bronze Age archaeology after the Second World War and the diffusion of cultural characteristics Guy De Mulder and Jean Bourgeois

3. Marcel Édouard Mariën (1918-1991) and the metal ages in Belgium. Undoing the Atlantic wall

Walter Leclercq and Eugène Warmenbol

4. Transmanche in the Penard/Rosnoën stage. Wearing the same sleeve or keeping at arm's length? Stuart Needham

5. At World's End: the Channel Bronze Age and the emergence and limits of the Atlantic complex Steven Matthews

6. Rythmes et contours de la géographie culturelle sur le littoral de la Manche entre le IIIe et le début du Ier millénaire Cyril Marcigny, Jean Bourgeois et Marc Talon

7. The Atlantic Early Iron Age in Gaul

Pierre-Yves Milcent

8. Following the Whale's Road: perceptions of the sea in prehistory Peter Clark

9. Circular funerary monuments at the beginning of the Bronze Age in the north of France: architecture and duration of use

Nathalie Buchez, Yann Lorin, Emmanuelle Leroy-Langelin, Armelle Masse, Angélique Sergent and Sébastien Toron with the collaboration of J. Brenot, K. Fechner, É. Lecher, E. Martial and Y. Petite

10. Evolution of rites and funerary systems during the Early and Middle Bronze Age in the north-west of France Ghislaine Billand, Isabelle Le Goff and Marc Talon

11. La nécropole de Soliers 'PA.EOLE' (14) : nouvelles données en faveur d'un complexe medio-atlantique Régis Issenmann, Capucine Tranchant, Alexis Corrochano et Émilie Dubreucq

12. Open Bronze Age settlement forms in the north of France: state of knowledge and study strategies Emmanuelle Leroy-Langelin, Yann Lorin, Armelle Masse, Angélique Sergent and Marc Talon

13. Les découvertes récentes de mobilier céramique Bronze ancien-début Bronze final dans le nord-ouest de la France Nathalie Buchez, Marianne Deckers, Caroline Gutierrez, Alain Henton et Marc Talon

14. Bronze Age ceramic traditions and the impact of the natural barrier: complex links between decoration, technique and social groups around the Channel 
15. Evolution des faciès céramiques au Bronze final et à l'aube du premier Âge du Fer, entre Somme, Escaut et rivages de la Manche (France, région Nord-Picardie) Alain Henton et Nathalie Buchez

16. The Channel: border and link during the Bronze Age Patrice Brun

17. Water between two worlds - reflections on the explanatory value of archaeological finds in a Bronze Age river landscape Christoph Huth

18. Le passage des Alpes : voyages et échanges entre l'Italie et la Suisse (2200-700 av. J.-C.) Mireille David-Elbiali 


\section{Preface}

The political vocabulary of Europe in the early part of the 21 st century has resonated with themes of boundary and difference, of boundaries between states, concepts of 'them' and 'us', a concern to resist change, to maintain the status $q u o$. The concerns of today do not reflect the nature of the long sweep of European history, however. Archaeologists and historians have long known about the ebb and flow of people as they moved across the continent over the millennia, of the ever-changing and porous borders between groups of people, the exchange of goods, ideas and the evolution of identities over time.

More particularly, the integration of professional archaeological research into the planning legislation of many European countries since the Valetta Convention for the Protection of the Archaeological Heritage of Europe in 1992 has resulted in an explosion of new knowledge about our European ancestors and the way they lived their lives. It was the recognition of the implications of this new data for the close maritime connections between peoples living in the Transmanche zone of northwestern Europe during the Bronze Age - around 3500 years ago - that led to the creation of the European project 'Boat 1550 BC' project in 2011. The project sought to bring together this new evidence of the strong ancient cultural links between the peoples of the region and present it to a wider audience. It brought together seven partners from three countries: the University of Lille 3/Maison européenne de l'homme et de la société de Lille, the Institut National de Recherches Archéologiques Preventives (INRAP), the Département du Pas-de-Calais and the town of Boulogne-sur-Mer from France, the Canterbury Archaeological Trust and Canterbury Christ Church University from England, and Ghent University from Belgium. It was financially supported by the European Union Interreg IV A '2 Mers Seas Zeeën' programme and the Conseil régional du Nord-Pas-de-Calais.

It was in the context of the 'Boat $1550 \mathrm{BC}$ ' project that a major academic conference was planned in collaboration with APRAB (l'Association pour la Promotion des Recherches Archéologiques sur l'Âge du Bronze) that brought together academic and professional archaeologists from all over Europe (and beyond) to discuss the new discoveries and research into the connections between people in the past. Its remit went beyond the study of the Transmanche zone and indeed the Bronze Age, but instead extended right across Europe, reflecting on a period of two millennia, from the middle of the 3rd millenium $\mathrm{BC}$ to the middle of the 1st millenium BC. The conference was held on 3-5 October 2012 at the Universite du Littoral in the beautiful historic town of Boulogne-sur-Mer, France.

The proceedings of the conference are a co-production of Oxbow Books and APRAB, with the financial support of the Ministère de la Culture et de la communication, INRAP, and the UMR (Unité Mixte de Recherche) 8164 Halma.

The conference organisers would like to thank The Université du Littoral, the Centre de la Mer Nausicaa, and the service archéologique de la Ville de Boulogne for their assistance and the warm welcome extended to this international symposium.

Thanks should also go to the conference steering committee for their work in making the conference a success; Sylvie Boulud, Peter Clark, Alain Henton, Isabelle Kerouanton, Thibault Lachenal, Emmanuelle Leroy-Langelin, Armelle Masse, Claude Mordant, Pierre-Yves Milcent, Théophane Nicolas, Brendan O'Connor and Rebecca Peake.

Peter Clark, Mark Duncan and Jane Elder of the Canterbury Archaeological Trust are also acknowledged for their help in bringing this volume to publication.

Taken together, these varied contributions offer a new and different perspective on the relationships between the peoples of Europe in the distant past, a perspective that we hope will find a wide audience and help inform all about the prehistoric context of our modern world and our appreciation of European identity today.

Lastly, we pause to remember and celebrate the lives of two outstanding scholars of European prehistory who have recently passed away; Richard Darrah, perhaps best known for his ground-breaking work on the Dover Bronze Age boat, and Colin Burgess, whose magisterial command of the European Bronze Age inspired generations of archaeologists. We hope this volume represents a modest tribute to their outstanding contribution to our knowledge of Europe's ancient history. 



\title{
7 \\ The Atlantic Early Iron Age in Gaul
}

\author{
Pierre-Yves Milcent
}

\begin{abstract}
The concept of the Atlantic Early Iron Age in Gaul is a recent one and is thus not necessarily self-evident. It was presented for the first time in 2005 during a round table in Italy focusing on Celtic prehistory (Milcent 2006) in order to explicitly define its scope and update our understanding of the concept. In order to gain a better grasp of the pertinence of the term, it is important to recall how the Early Iron Age of the northwestern regions of Gaul was identified, then dispel any tenacious biases inherited from former strata of research, particularly for the Champagne region. In addition, we will see that this article slightly overruns the traditionally allotted chronological framework for the first Iron Age, as materials and sites from the whole of the 5th century BC are also taken into consideration.
\end{abstract}

Keywords: Early Iron Age; Atlantic networks; Medio-Atlantic societies; Champagne; La Tène genesis.

\section{Résumé}

"Le concept de premier Âge du fer atlantique en Gaule est récent et ne va donc pas de soi. Il a été présenté une première fois en 2005 durant une table ronde en Italie consacrée à la "Préhistoire des Celtes» (Milcent 2006). Je souhaite ici en détailler l'explicitation, la portée, et actualiser son appréhension. Pour mieux saisir la pertinence du concept, il est important de rappeler de quelle manière on a pu, ou non, identifier par le passé le premier Âge du fer des régions nord-occidentales de la Gaule. Il est nécessaire aussi de dissiper les préjugés tenaces hérités des premiers temps de la recherche, en particulier pour la Champagne rattachée à tort au monde hallstattien. Cet article débordera légèrement du cadre chronologique traditionnellement attribué au premier $\hat{A} g e d u$ fer en prenant en considération l'ensemble du Ve siècle avant notre ère. Il s'agira notamment de mettre en évidence certains des traits principaux des cultures matérielles du premier Âge du fer atlantique».

Mots-clés: premier Âge du fer, réseaux atlantiques, sociétés médio-atlantiques, Champagne, genèse des cultures matérielles de La Tène

\section{An Early Iron Age without a name: historiographical overview}

In the most northern and western regions of Gaul in the geographical sense of the term (Fig. 7.1), the notion of the Early Iron Age remained vague for a long time. Its existence was at times denied, and at best often limited to a transitional stage between the Late Bronze Age and the Early La Tène period (Déchelette 1913 [1927], 40, 43 and 76; Giot et al.
1979). This period was at times the focus of Bronze Age specialists, serving as a conclusion to their research (Briard 1965; Blanchet 1984), and at times analysed by specialists of the Late Iron Age, as a prelude to their work (Hatt and Roualet 1976; 1977; Demoule 1999). Therefore, apart from some exceptions (Mariën 1958), the Early Iron Age of these northwestern regions was not treated as a fully-fledged period with its own characteristics. 
The thesis that these zones were distant peripheries, turned towards the Atlantic and more or less lagging behind the supposed central regions, prevailed for a long time and has still not totally disappeared. It stipulated that these lands were barely affected by the development of iron metallurgy, or only at a late period corresponding to the Late Hallstatt, or even the Early La Tène of continental regions, giving rise to the idea of a prolongation of the Late Bronze Age in these regions, which was more or less equivalent to the Early Hallstatt and sometimes even to the Middle Hallstatt of continental cultures (Giot 1950, 338; Brun 1987, 53-4). Even today in scientific publications, it is not rare to come across Armorican socketed pseudo-axes incorrectly attributed to an 'extended Late Bronze Age', or, for the more massive specimens, to the Atlantic Late Bronze Age 3. Even when they are not functional, they are presumed to represent the persistence of mainly bronze tool production until the 6th century $\mathrm{BC}$, and the ignorance of iron smelting and iron forging.

As for the emergence of a full Iron Age, it was deemed to result mainly from external stimuli, driven by the migrations of Proto-Celtic Hallstattian populations, according to early works (Déchelette 1913 [1927], 168; Mariën 1958), or by contributions and influences from both the continental domain and the Mediterranean, according to more recent approaches (Giot et al. 1979; Hatt and Roualet 1977; Brun 1987). Note that the emergence of typical La Tène culture features in these regions is generally considered to follow a comparable centrifugal schema, with a late Celtisation resulting from a more or less cumulative acculturation process, depending on the authors.

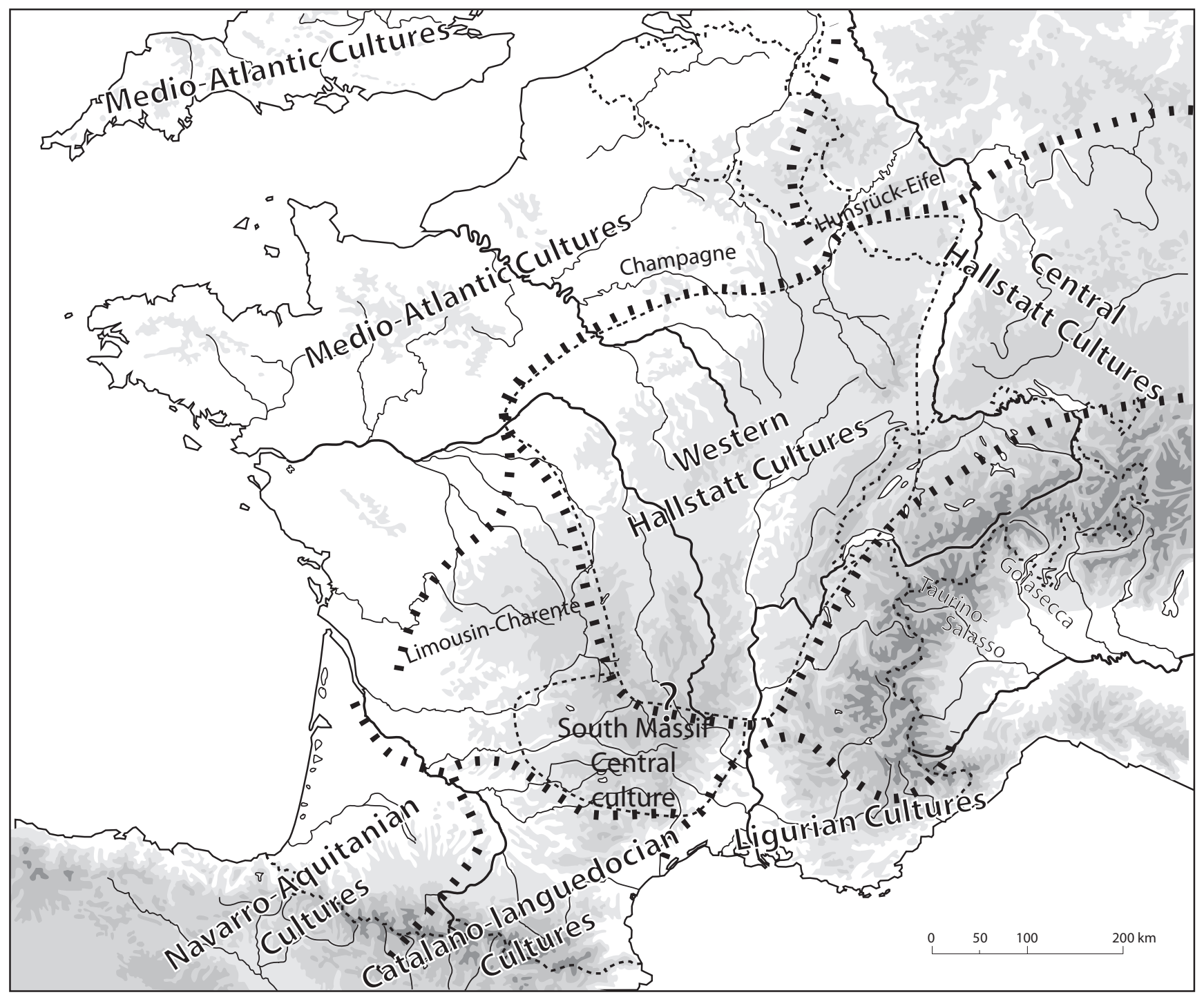

Fig. 7.1. Cultural entities in Gaul in the Early Iron Age. 
These diffusionist, or at times even migrationist paradigms are based on 'centre-periphery'-type models and evoke images of northwestern regions submerged by migrations, or lagging behind, in a process of acculturation. Towards the end of the 1980s, they were abandoned, although no detailed models replaced them, or they were revised, without being entirely rejected, by the world-economy concept assigning a role of passive procurement to these territories on behalf of allegedly more dynamic and advanced regions in Central Europe and the Mediterranean.

Thus, the same concept always prevails when a model is formulated; that is to say innovation and civilisation are located in the Mediterranean, the active reception of these stimuli is based in Central Europe and beyond that, inertia and passivity are associated with the west and north of Europe. This idea is extremely ancient as it is more or less the same as that presented by Greek historians, and Herodotus in particular.

Nonetheless, it would be very unfair to formulate this severe review without recalling that the materials and archaeological sites from the Early Iron Age in northwestern regions remained very poorly identified for a long time, mainly on account of more modest-looking or more difficult remains to identify than elsewhere. Unlike the Hallstattian or Mediterranean regions of Gaul, pottery in these zones bears little decoration and displays rather simple profile shapes, settlements are never clustered together to form large agglomerations, and those that have been excavated have yielded few objects. In the same way, tombs can be rare or only exceptionally preserve spectacular objects, even for the most privileged graves. In such conditions, it is a difficult challenge to identify a northwestern Early Iron Age and we cannot criticise our predecessors for not having clearly identified this chrono-cultural facies.

However, over the past 20 years discoveries have multiplied, mostly from rescue archaeology, and at last we have evidence of settlements. In the same way, grave mapping is beginning to take shape, after remaining extremely scant for a long period of time. Nevertheless, the identification of a northwestern Early Iron Age in its own right, and not one modelled on that of regions further south or east, is still difficult to establish. For a long time, this period had no specific name. As proof of this, we only need to refer to the widespread use of the German nomenclature passed on from the work of P. Reinecke. In this way, over the past 20 years, remains found in the northwest of France are said to date from the 'Hallstatt C' or the 'Hallstatt D'. This chronological nomenclature and associated periodisation cannot, however, be adopted, or even adapted: firstly because from a methodological point of view, it is preferable not to associate a cultural dimension with chronological nomenclature (cf. for example the chronology of the Urnfields by W. Kimmig, laden with questionable historical implications), as explained by
J. Collis (1986) among others, and secondly and especially because this chrono-cultural construction was developed and defined on the basis of funerary goods from Central Europe, and particularly from southern Germany. Connections with materials from the northwest of France or Belgium are thus rarely substantiated, apart from for several very particular and rare metallic objects, whereas nothing leads us to reasonably consider that the evolution of societies near the Atlantic Ocean and the Channel could have occurred in step with their Central European counterparts. Apart from the fact that this transposition of the 'Reinecke' chronology appears to be totally methodologically arbitrary and incongruous, it implicitly recalls that the Early Iron Age of the northwestern regions of Gaul is not considered to be autonomous, with its own chronological dynamics. In other words, this reveals that the old diffusionist stereotypes that we thought we had discarded 30 years ago, relegating this western zone to the back-benches of Europe at the beginning of the Iron Age, remain very present today and still colonise minds and vocabulary.

\section{Deconstructing preconceived notions}

Before envisaging the existence of a specific Early Iron Age in northwestern Gaul, it appears essential to recall the main preconceived notions altering its perception, in order to demonstrate that they are unfounded. Our aim is not to establish an inventory of these notions, but simply to deconstruct the main concepts.

\section{Until the 6th century $B C$, an exclusive bronze metallurgy and hoard practices inherited from the Late Bronze Age?}

Like in most of the other regions of temperate Europe, the metallurgy of copper alloys during the Early Iron Age remains in fact poorly known in northwestern Gaul. Quantitatively, Armorican socketed pseudo-axes provide most of the information. These productions follow on from functional Late Bronze Age socketed axes and mainly date from the 7th-6th centuries BC (Gomez de Soto et al. 2009; Milcent 2012, 161-7; Milcent in press). In actual fact, they have little in common with their 'precursors' from the end of the Bronze Age: apart from some rare older models, they were cast using an alloy rich in lead; they are small in size, often miniatures; their socket is deep and hardly leaves room for the cutting edge; they are not functional tools and therefore do not present any traces of sharpening. Apart from rare exceptions, they are assembled as roughouts, but with traces of circulation, in over 300 very monotonous hoards exclusively made up of these objects. They thus have no connection whatsoever with the real Late Bronze Age socketed axes, which are morphologically varied and often found used and broken, along with other heteroclite 
objects, in jumbled hoards predating the 8th century BC. The production and depositing of the Armorican pseudo-axes thus corresponds to a very original phenomenon, specific to the Armorican Early Iron Age. This phenomenon can probably be explained by the pre-monetary use of these pseudo-axes and by their definitive abandonment as part of ritualised practices (Milcent in press). We cannot thus use them to argue for the continuity of an industry and hoard practices from the Atlantic Late Bronze Age. On the contrary, these sets of pseudo-axes provide evidence of a profound mutation of the position accorded to copper alloy products in the socioeconomic sphere during the Early Iron Age.

\section{A late emergence of iron metallurgy under Hallstattian, or even Mediterranean influence?}

From the end of the Late Bronze Age, small iron objects found throughout the zone of Atlantic network circulation, from Extremadura to Scotland (Vilaça 2013; Milcent 2012, 141; Needham 2007, 49-52), provide evidence of knowledge of a new metal, albeit limited, as in temperate Europe. It is difficult to identify the place of fabrication of these elements, which do not constitute proof of the mastery of iron metallurgy as they could be imported or made from imported refined iron bars. However, it is important to recall the existence of forge waste (scalings) associated with a settlement apparently dating from the 10th century BC in the south of England (Hartshill Quarry in Berkshire; Collard et al. 2006) and iron work slag from the 9th century BC at Bonnée in the Centre region of France, on the fringes of the Bronze Atlantic zone (Joly et al. 2011). Above all, it is imperative to reiterate the fact that evidence of iron metallurgy during the Late Bronze Age in the continental domain is no more frequent or more impressive (Gomez de Soto and Kerouanton 2009).

More significantly, from the beginning of the Early Iron Age, during the 8th century BC, we find several large-sized Atlantic iron productions: Holme-Pierrepoint type swords, looped socketed axes, to cite but a few examples (Milcent 2012, 143; pl. 65, no. 7 and 9; pl. 72, no. 17). These exceptional objects were undoubtedly reserved for the elite and demonstrate for the first time a real mastery of forge techniques. They do not appear to be less frequent than their very rare equivalents from the east of France or Languedoc. In western Languedoc, in contact with Phoenician, Greek or Etruscan tradesmen and artisans, the 'Launacian' industry, fossilised in non-funerary hoards, shows that essential instruments, such as axes and spearheads, were still produced in bronze until the beginning of the 6th century BC. In these conditions, it is not legitimate to envisage any significant lag in iron metallurgy in the northwest of Gaul compared to more eastern or more southerly regions. In addition, for a period corresponding to the 7th century, a site such as Choisy-au-Bac (Oise) yielded two major forges
(Blanchet 1984, 423-5, fig. 245). During the Boulogne colloquium, the discovery of forge residues dating from the beginning of the Iron Age at Saultain (Nord) was reported by N. Buchez and A. Henton.

Traces of primary iron production are now very well established for the Early Iron Age in the region of Le Mans (Sarthe), in Upper Brittany, as well as in the Evreux region in Upper Normandy (at least 11 sites). Paradoxically, these oldest bloomeries, for once-off use and of trapped slag type, are much better known and more frequent in the northwest than in the east of France (Cabboi et al. 2007, 58), even though this mainly denotes differential research. The discoveries of these past 15 years did not come as much of a surprise as hoards of more or less refined bi-pyramidal iron bar masses have been known for a long time in some of these northwestern regions, particularly in Brittany (where 130 bars have been recorded, corresponding to about $800 \mathrm{~kg}$ of metal). As most of these bars present a specific morphology which is not found elsewhere, apart from occasional finds in the south of England (elongated bars, variant BLS5 of Marion Berranger's classification; Berranger 2014, 69, 90; fig. 32), there is no reason to assume that these objects were produced outside northwestern Gaul.

\section{A world under continental pressure or influence?}

The theory that the Late Bronze Age in Atlantic regions was under pressure from the Continent, as shown in particular by Rhine-Swiss-eastern France (RSFO) influences, then Hallstattian influences, is widespread. In this way, vast regions in the north and west of France were considered to have integrated into the orbit of the Continental domain, as a result of migrations, or more recently in a more moderated vision, on account of cultural transgression and acculturation. After $800 \mathrm{BC}$ in particular, the Atlantic cultural area would have shrunk rapidly on the Continent, to such an extent that it would be difficult to envisage that it was not a peripheral facies of the Hallstattian world, or under Hallstattian influence, apart perhaps from the Armorican Massif and the Channel coastline. According to this paradigm, most of the material culture of these northwestern regions would be importations or the influence of Central Europe. We will not revisit the very complex and rather balanced exchange dynamics operating during the Late Bronze Age between the Atlantic and the continental domains (Milcent 2012) as we would not have enough space to assess this question, which is, moreover, not the central issue of this paper. For the ensuing period, it is clear that these links are much less simple and asymmetric than previously thought, and that the cultural area preferentially opened towards the Channel and the Atlantic, does not appear to be specially confined to a fringe of Gaul. Several cases will be cited as examples here, such as hand weapons, domestic and funerary architecture. A special mention should be reserved for the Champagne region, which was responsible for 
some of the intellectual barriers inhibiting the identification of an Atlantic Early Iron Age.

In relation to weapons, we will not examine in any detail an argument presented for the past 15 years, i.e. that griptongue swords with pistiliform blades from the beginning of the Iron Age, incorrectly referred to as 'Hallstattian', are originally North Atlantic products, and that they were adopted from the 8th century BC onwards by the majority of the continental elite, with adaptations. What is new, is that the examination of other emblematic objects from the early continental Hallstatt, also reveals Atlantic heritage or strong Atlantic influences. This is true of razors, certain horse harnessing and wagon elements, vessels and situlae in bronze sheets (Milcent 2009; 2012, 149-53; 2015). These are thus forms of an 'Atlantic way of life' that spread a little everywhere throughout middle Europe during the 8th century BC.

A rather similar process is at work at the end of the Early Iron Age, with tanged hilt Medio-Atlantic daggers, often called 'Jogassians'. These arms and their metallic sheaths appear simultaneously for the first time on either side of the eastern Channel, particularly in Champagne and in the lower Thames Basin, and are then adopted and distributed from the second half of the 5th century onwards, throughout what was in the process of becoming the Latenian domain (Milcent 2009). The parallel diffusion from west to east, of filiform fibulae with short springs and a pellet or disc-shaped foot (Dehn and Stöllner 1996; Milcent 2006, 96, fig. 10) implies that other material culture traits of Atlantic ancestry or dispatched through the Atlantic domain, also accompanied these weapons in one way or another.

The case of architecture is more original as it is not called upon to account for the cultural dynamics of the Early Iron Age. As far as the domestic buildings are concerned, we know that the circular plan examples discovered in north-west Gaul are taken to be Atlantic, or to be more precise, closely linked with the British Isles, as comparable 'houses' from an architectural and technical viewpoint were identified across the Channel. In the British Isles, these circular buildings are by far the predominant architectural form, but are not exclusively used for the construction of houses. Links on either side of the Channel appear to be all the more likely in light of the fact that continental circular 'houses' are rare and are concentrated in the regions bordering the Channel, at least during the Early and Middle Bronze Age (Fig. 7.2). Unlike traditional perspectives would have us believe, these circular houses do not become rarer during the Late Bronze Age and do not disappear from the continent during the Early Iron Age. On the contrary, the sites on which we find them appear to be more frequent than at the beginning of the sequence, and above all, clearly advance inland during the Early Iron Age, particularly towards the south of Champagne (Fig. 7.2). The observed dynamics are thus opposed to usual assumptions. Unfortunately, due to dating problems, it is not yet possible to accurately date these buildings in the Early Iron Age and to provide details on the dynamics of this extension into Gaul. However, it is important to underline that circular buildings are still well recorded in northwestern Gaul during the Late Iron Age (Dechezleprêtre and Ginoux 2005).

If we now consider funerary architecture, a similar process may be observable, but on a totally different scale. Generally, in middle Europe, the emergence of funerary enclosures made up of a more or less square ditch, often lined with a palisade, containing a group of family burials, is associated with the advent of La Tène cultures, during the 5th century $\mathrm{BC}$. The model of these funerary structures with strong ritual and cosmological connotations was attributed to regions considered to correspond to the birth of material La Tène cultures, particularly Bohemia, Hunsrück Eifel and Champagne. Although trenched quadrilateral funerary enclosures are known there from the 5 th century BC onwards, they were not exclusive to these regions, as shown by the example of contemporaneous necropolises in Brittany (Villard et al. 2013) or in eastern Languedoc (Séjalon and Dedet 2003), to cite only a few distant examples. But, above all, recent discoveries confirm that prototypes exist from the end of the 7th century $\mathrm{BC}$, on the Continental Channel coastline, from Lower Normandy to Pas-de-Calais (Fig. 7.3, nos 4-5). Similar, yet older funerary enclosures are sporadically recorded in Flanders and the north of France, during the Atlantic Late Bronze Age 2 and the Atlantic Early Iron Age 1 (Fig. 7.3, nos 1-3). Like certain canonical Latenian examples, square enclosures from the full Atlantic Early Iron Age can be associated with a palisade and delimit burial pit graves that appear to correspond to family groups, like in Basly in Calvados (Fig. 7.3, no. 5). This transition from circular funerary enclosures to quadrangular enclosures must represent a major change in mentalities and it is interesting to attempt to identify the leading regions of this transformation.

\section{Champagne: on the fringes of the Atlantic area}

These cases show that it is no longer possible to consider today that the northwestern societies of Gaul were accountable to or under the influence of Hallstattian regions during the Early Iron Age. But we must refrain from adopting the opposite model to that criticized here, by inversing the poles in a caricatured way. In view of their extension, the regions linked by the networks referred to as Atlantic were never a centre in relation to others, no more than the Hallstattian world. All of this argues in favour of abandoning 'centreperiphery' type models for the European Early Iron Age. The question now is to comprehend the links between the 


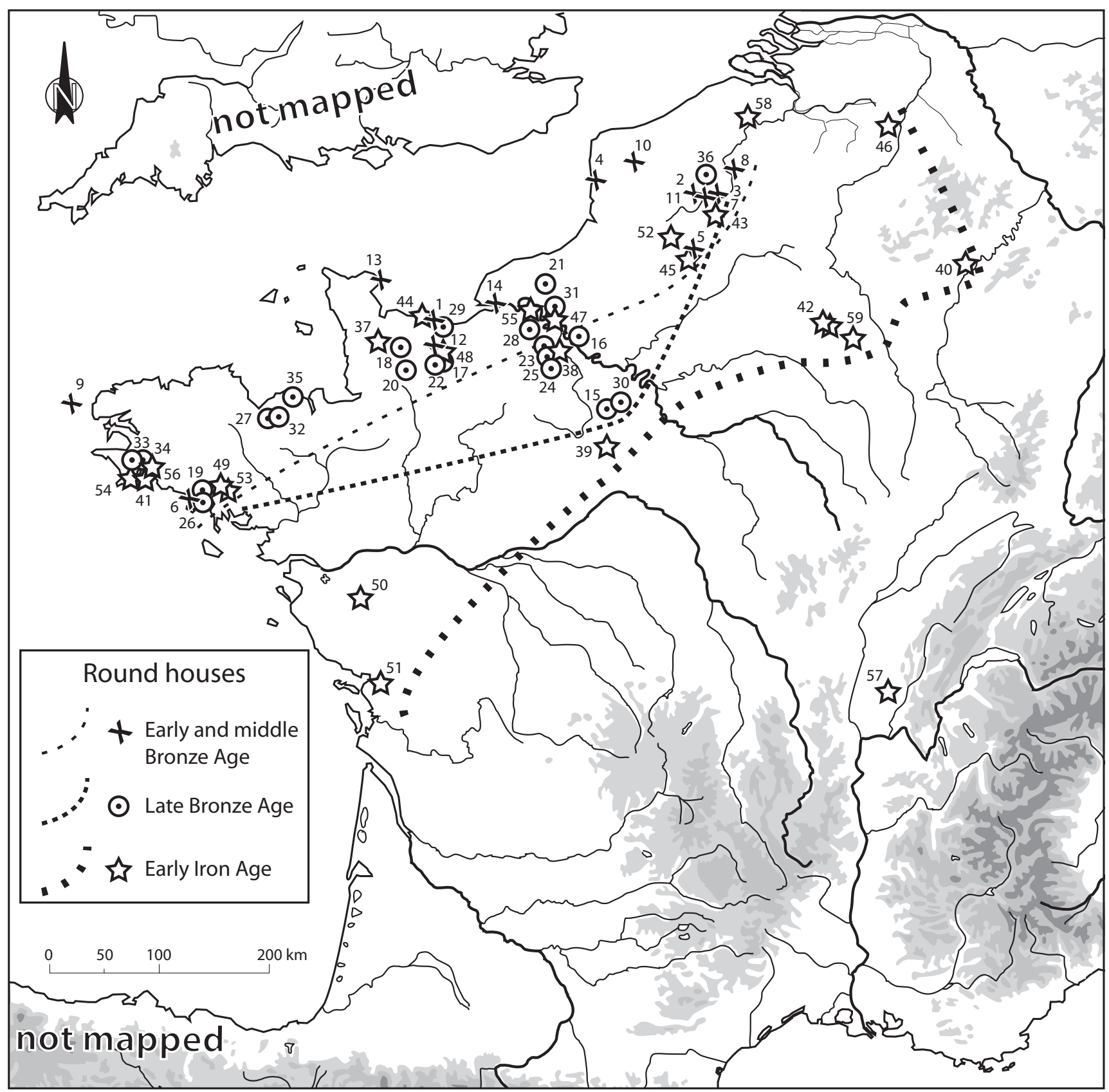

Fig. 7.2. Distribution of round houses dating to the Bronze Age or Early Iron Age. Early and Middle Bronze Age: Bernière-sur-Mer (1); Brebières (2); Erre (3); Etaples-sur-Mer (4); Eterpigny-Barleux (5); Guidel (6); Lauwin-Planque (7); Lesdain (8); Ouessant (9); Rebecques (10); Roeux (11); Saint-Martin-de-Fontenay (12); Saint-Vaast-la-Hougue (13); Saint-Vigor-d'Ymonville (14). Late Bronze Age: Auneau (15); Bouafles (16); Cagny (17); Cahagnes (18); Caudan (19); Condé-sur-Noireau (20); Etaimpuis (21); Fontenay-leMarmion (22); Gravigny (23); Grossoeuvre (24); Guichainville (25); Guidel (26); Lamballe (27); Malleville-sur-le-Bec (28); Mathieu (29); Mignières (30); Mont-Saint-Aignan (31); Plédéliac (32); Pluguffan (33); Quimper (34); Saint-Jacut-de-la-Mer (35); Seclin (36). Early and transitional Later Iron Age: Agneaux (37); Alizay (38); Allaines-Mervilliers (39); Beaufort (40); Bénodet (41); Bezannes (42); Bourlon (43); Courseulles-sur-Mer (44); Ennemain (45); Grote-Spouwen (46); Honguemare-Guénouville (47); Ifs (48); Inzizac-Lochrist (49); La Gaubretière (50); Longèves (51); Méaulte (52); Pluvigner (53); Pont l'Abbé (54); Poses (55); Quimper (56); Saint-Just (57); Sint-Martens-Latem (58); Suippes (59).

societies of this period in a more complex, dynamic and multilateral way. This is in particular why the term 'MedioAtlantic' and not 'Central-Atlantic' Early Iron Age was coined to describe regions in the northwest of Gaul and the south of Great Britain, in an intermediary situation in the area of networks preferentially constructed in westernmost 


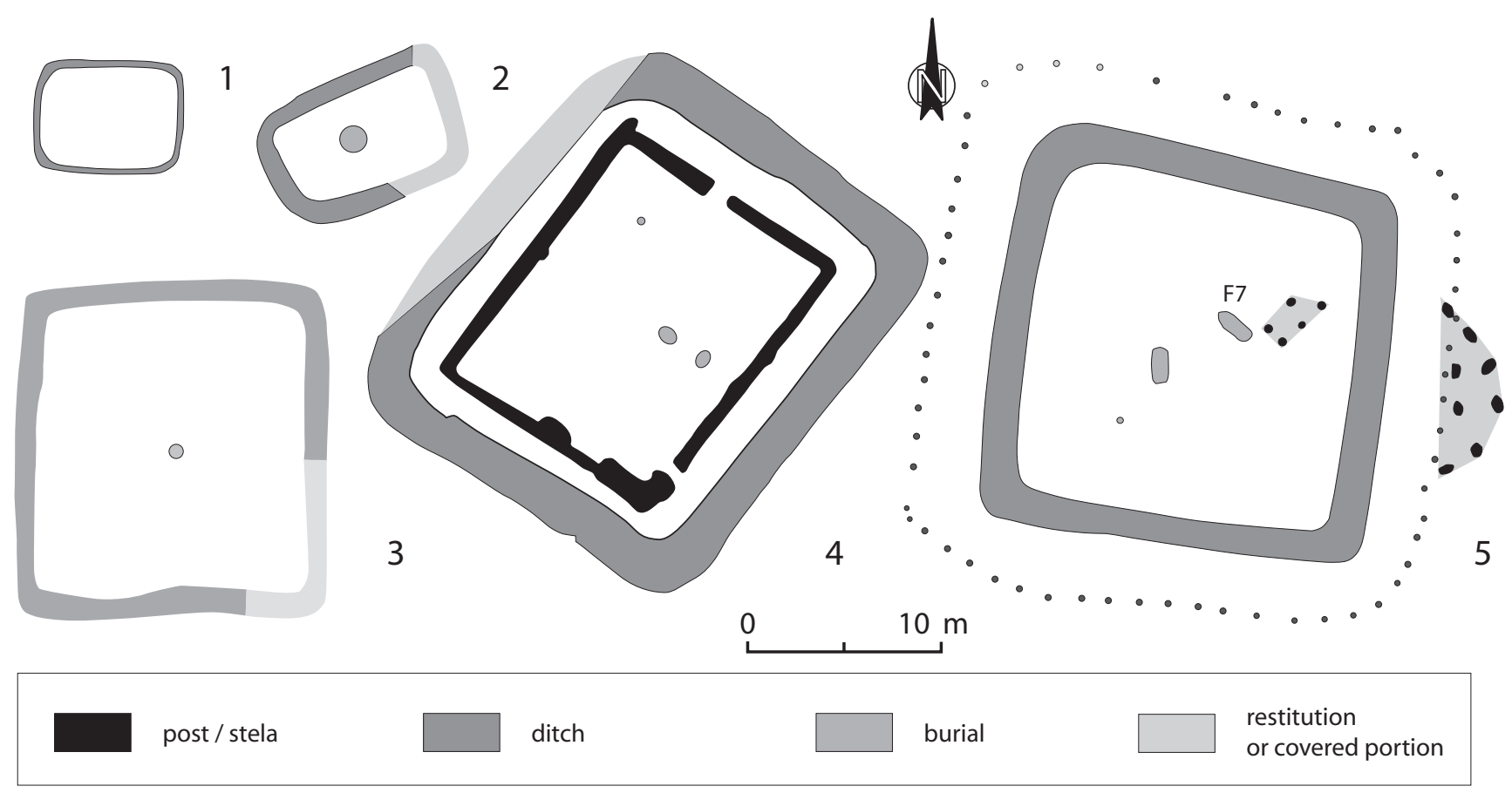

Fig. 7.3. Late Bronze Age medio-Atlantic sub-rectangular funerary enclosures (nos 1-2: 11th-10th centuries BC) to the mid-Early Iron Age (no. 3: 8th-first half of the 7th century BC; nos 4-5: 2nd half of the 7th-early 6th century BC). No. 1: Tagnon, Ardennes (after Le Goff and Guillot 1992); no. 2: Thourotte, Oise (after Blanchet and Talon 2005); no. 3: Destelbergen, Flandres occidentales (after De Laet et al. 1986, Fig. 29) ; no. 4: Eterville, Calvados (after Jahier 2005) ; no. 5: Basly, Calvados (after San Juan and Le Goff 2003).

Europe. This does not imply that the Atlantic networks would be in competition with the others to the point that clear limits could be observed around their peripheries, and still less that monothetic groups existed, that is, where all the main traits would be purely Atlantic. Instead, we observe the occurrence of complex interconnections and many examples of cultural transitions with no clear-cut limits, apart from some exceptions, which creates difficulties when we attempt to visually and cartographically depict these phenomena. Champagne provides a good example of this cultural mixing. This region warrants special consideration as for a long time it was the focus of attention and still serves as a reference for the cultural characterisation of the most northern and western regions of Gaul. Champagne has many points in common with these latter regions, is considered as Hallstattian, and would be a key element arguing for the inexistence of original and Atlantic cultural entities during the Early Iron Age. It is thus crucial to correctly identify and analyse the main cultural features of Champagne.

The very particular historiographical status of this region is explained by the abundant funerary discoveries dating from the end of the Early Iron Age and particularly from the beginning of the Late Iron Age, as well as the early exploration of settlements from these periods. The Champagne geological substratum is mainly made up of chalky plateaus, which explains why sites are easier to detect than elsewhere, and why they appear to be more frequent or rich. Due to fact that abundant sites were excavated as early as the 19th century, Champagne was often considered as one of the main centres of the cradle of Latenian societies, supposed to occupy a wide crescent extending beyond the classical Hallstattian domain, from Champagne to Hunsrück Eifel to Bohemia. However, this was not based on any detailed or decisive argument. The earliest Iron Age graves from the Champagne region were attributed to the end of the Hallstatt Early Iron Age on account of several discoveries of fibulae of Hallstattian morphology and technology. But also because, due to circular reasoning, the Early Latenian Champagne tombs were affiliated to an ancestral Hallstatt material culture (Hatt and Roualet 1977, 11). For all these reasons, the material culture from the end of the Early Iron Age in Champagne and the outlying areas, described as Jogassian (from the eponymous necropolis at Chouilly 'Les Jogasses') following the terminology of P. M. Favret, or Aisne-Marne stage 1 according to that of J.-P. Demoule, is still considered by most protohistorians as one of the westernmost manifestations of a strictly Hallstattian cultural facies. This is why the recurring perceived affinities between the northwesternmost regions of Gaul and Jogassian culture are sometimes deemed to be surprising, and generally interpreted in terms of profound diffusions of Hallstattian influences towards the northwest.

In reality, the link between Jogassian culture and the Hallstatt complex should not be taken for granted and 
disproportionate weight has been given to the Hallstattian fibulae from Champagne as regards the identity of the region in terms of material culture. What really remains of this allegedly Hallstatt material culture if we exclude these fibulae from the debate, a lot of which (in particular the drum fibulae) are in actual fact importations from more southerly neighbouring and truly Hallstattian regions? What is left if we leave out the elements of personal adornment that appear to point to the presence of foreigners or adhesion to an 'international' elite fashion, such as basket-shaped pendants, glass beads, bronze tubular torcs or 'armlet' type bracelets? When these are discounted, nothing specifically Hallstattian remains in Jogassian necropolises and settlements. The weapons, especially the aforementioned Jogassian daggers, but also the spear heads, the bows and arrows for which we sometimes find the quiver (Hatt and Roualet 1976, pl. ii), have no exact equivalent in the Hallstattian domain, strictly speaking. Annular adornments other than those mentioned above are specific to Champagne, or else very simple and ubiquitous. As for Champagne pottery productions, they are mainly characterized by angular carinated profiles which later become widespread during the 5 th century $\mathrm{BC}$ and are more similar to those from regions situated further west or further north (Fig. 7.4). But, above all, funerary practices, which are, with pottery, one of the best criteria of cultural identification, display few associations with the Hallstattian world. Jogassian graves are practically exclusively inhumation burials, and are not installed in tumuli used as family cemeteries supprimer virgule, like in the Hallstattian world from Ha D1-2 and Ha D3. Individual inhumations are laid out in a sub-rectangular pit, which can be deep, and is not overlain by a tumulus of sufficient dimensions to have left any trace, apart from a few exceptions. They often form small groups of aligned or parallel pits, prefiguring the organisation of certain Latenian necropolises, but have no equivalent in the West Hallstattian world. In addition, they often contain a food deposit, probably corresponding to the remains of a funerary meal, made up of one or several pottery vessels and animal bones. These food deposits never appear in Hallstattian tombs in the eastern centre and the east of France. Only the presence of drinking vessels has been recorded in several of these latter tombs.

On a different level, the absence of elitist graves corresponding to the Hallstattian model of the tomb with a four-wheeled wagon beneath a large tumulus, or to the west Hallstattian model of a cremation deposited in a bronze urn under a tumulus (cf. map of these tombs: Verger 1995, fig. 1 and 47; Milcent 2003, fig. 234), is a sign that the Champagne elite never adhered to the very specific funerary ideologies of the east and the eastern centre of Gaul. As observed before, exceptions have been discovered only in the south of Champagne, in the region of Troyes-Lavau, in a sector bordering the Hallstattian world in the strict sense of the term (Verger 1995, 363; Milcent 2014, ill. 4.11).
More generally, our knowledge of settlements, the territorial and socio-economic organisation of Champagne at the end of the Early Iron Age and the very beginning of the following period, does not point to any particular affinities with Hallstattian Gaul. There are no similar protourban agglomerations, like that of Bourges and no princely residences, such as Vix (Milcent 2014). Settlement appears to be relatively dispersed and at most, we can identify large hamlets or small villages with loose organisation, alongside very structured farms (Villes 2000).

In the same way, it is significant that in spite of the fact that thousands of tombs have been excavated in Champagne, early Mediterranean imports are only anecdotally represented and belong to very banal products (elements of at times unrefined coral, perhaps glass beads). ${ }^{1}$ They thus have nothing to do with the hundreds of very diversified Mediterranean imports present in west Hallstattian regions, which are sometimes issued from prestigious productions (Guggisberg 2004). This implies that Champagne remained rather hermetic, like most of northwestern Gaul, to the major ideological and material exchange currents that structured the tight relations established between the Hallstattian and Mediterranean domains at this time.

For all these reasons, Champagne should now be removed from the Hallstattian world, strictly speaking, in the same way as Hunsrück-Eifel. Widening the Hallstattian world to Champagne was an interpretative illusion, inherited from the confusion of the first half of the 20th century, which muddles the issue and the understanding of cultural dynamics at the end of the Early Iron Age. We cannot deny that Champagne remains original in certain respects and that it presents affinities with adjacent Hallstattian regions, which is logical given its geographical location in contact with the eastern centre of Gaul and the polythetic aspect of the material cultures, but it is increasingly apparent that it shares a majority of cultural traits with more northern and western regions. It is notably on this basis that it seems possible to identify an Early Iron Age in the northwestern arc of Gaul, i.e., from Gironde to Meuse, with different cultural and socio-economic traits to those of continental regions. We now propose to describe this Atlantic Early Iron Age and to consider its geographic influence and also the links that it appears to maintain with the Atlantic Late Bronze Age, identified during the 1940s.

\section{Assessing the Atlantic Early Iron Age in Gaul}

As its name suggests, the concept of the Atlantic Early Iron Age is based on two main dimensions, one of which is chronological, the other geographic and cultural. In concrete terms, this implies that we can identify this period by differentiating it from the preceding Late Bronze Age and the ensuing Late Iron Age. It also suggests that the archaeological materials from this period present a 


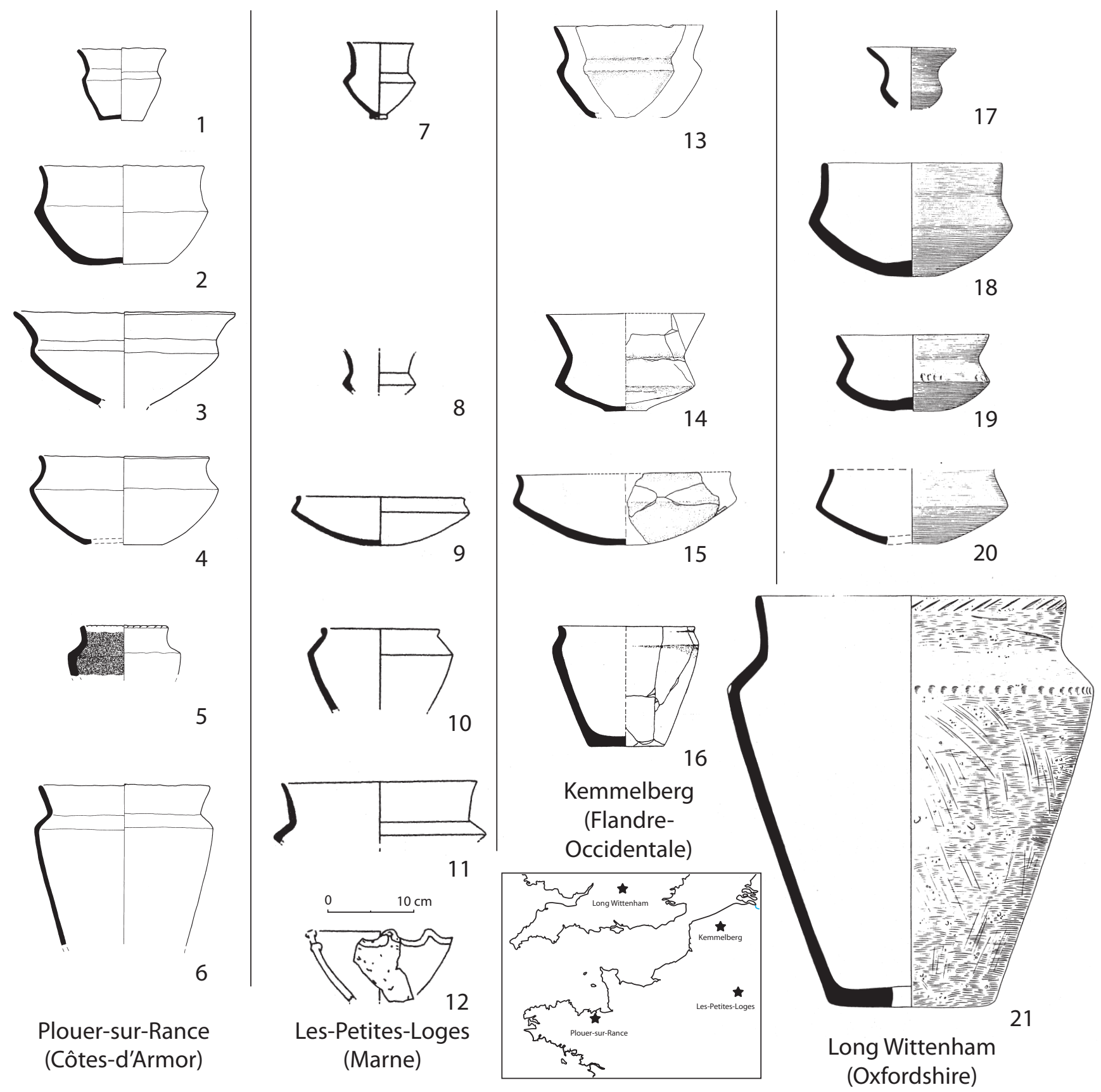

Fig. 7.4. Comparative table of selected series of medio-Atlantic ceramics of the 5th century BC from Brittany (1-6; Ménez 1996), Champagne (7-12 ; Saurel 2007), Belgian Flanders (13-6 ; Van Doorselaer et al. 1987) and southern England (17-21 ; Harding 1972). At same scale.

sufficient number of specific features to distinguish them from continental or southern cultures. In order for these traits to be considered specific, they must be preferentially distributed throughout regions close to the Atlantic and the seas (the Channel and the southwest of the North Sea) and rivers (Loire, Seine ...), sometimes prolonging this ocean a long way from its shorelines.

Assuming that the Atlantic Early Iron Age represents a kind of continuum with the Atlantic Late Bronze Age, this would also imply that it would not be confined to the northwestern regions of Gaul. As in the past, there would be shared material culture traits with other European regions bordering the northern Atlantic and its eastern ramifications, particularly Great Britain. Forms of exchange and links with these other regions should also be perceptible. From our perspective, it is not a case of identifying a homogeneous super or supra-cultural complex extending over the westernmost European territory, beyond Atlantic 
Gaul. The concept of the Atlantic Early Iron Age, like that of the Atlantic Late Bronze Age, corresponds rather to the identification of the importance of a network of contacts preferentially linking, for diverse regions (geographic, historical, socio-economic...), different cultures through different aspects, to the point of revealing convergences between these cultures, perhaps in the same way that certain
Mediterranean regions shared cultural traits designated as Orientalising, during the same period.

As for the chronological dimension, it is not necessary to revisit the individualisation of a true Early Iron Age as this is more or less generally accepted. Today, the remaining challenge is its internal periodisation and absolute chronological order. Proposals to this end only really

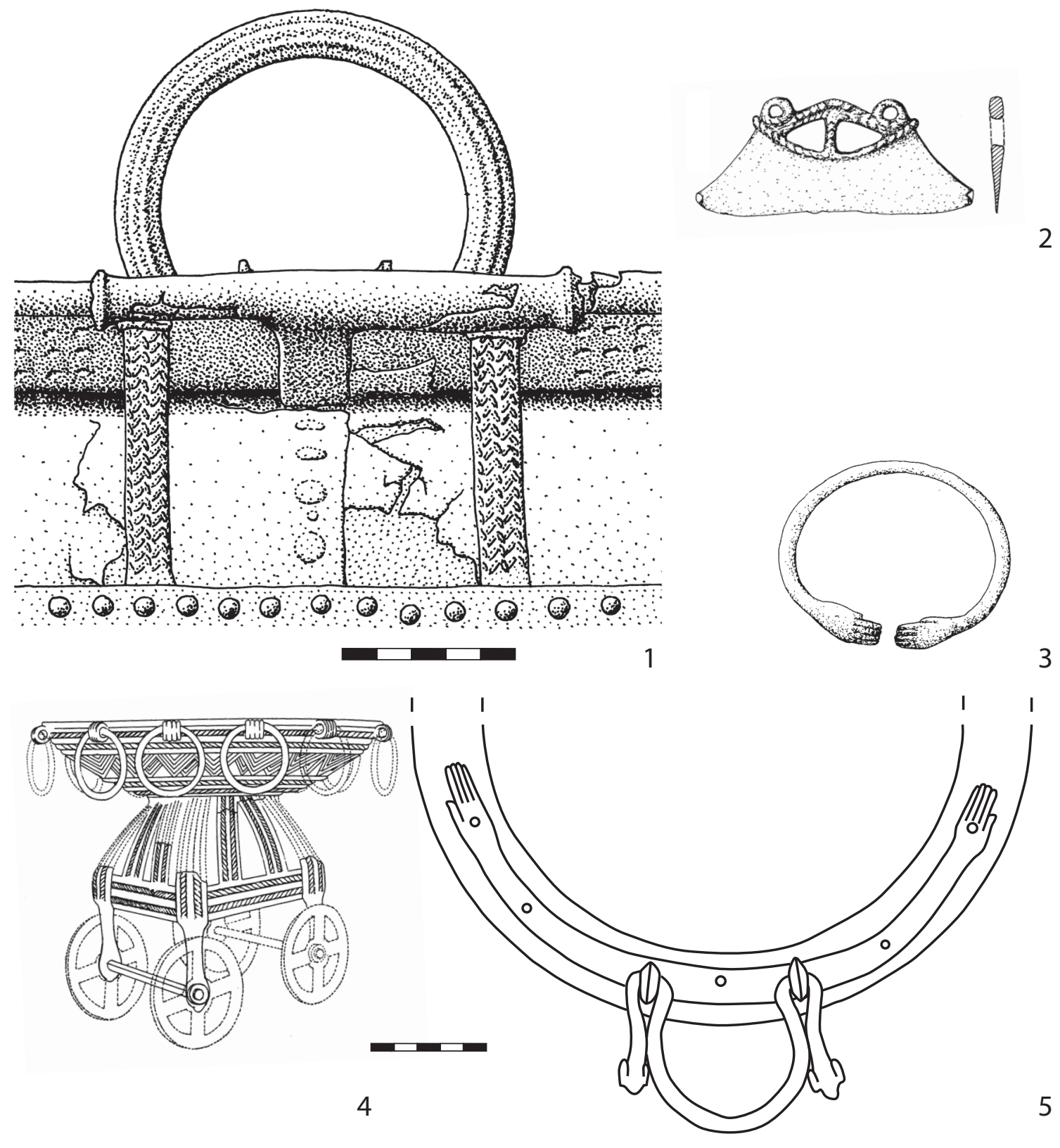

Fig. 7.5. Atlantic objects of the Early Iron Age with braided decoration of Syro-Cypriot style (1-2) and ornamentation with prophylactic hands of Near Eastern inspiration (3). For comparison, objects of Punic inspiration discovered in the Iberian Peninsula (4-5). 1: attachment loop of a cauldron from Llyn Fawr (Wales) of the Early Iron Age (Gerloff 2010, pl. 73); 2: razor from Saint-Leu-d'Esserent (Oise) of the Early Iron Age (Blanchet et al 1978); 3: bracelet from Saint-Pierre-sur-Dives (Calvados) of the Early Iron Age (Verney 1993 Fig. 8 no. 11); 4: miniature chariot from the Baiões hoard (Beira Alta) dated to the Late Bronze Age (Silva 1986); 5: Western Phoenician basin attachment from Cañada de Ruiz Sánchez in Carmona (Sevilla), of the 7th century BC (after Jimenez Avila 2002, pl. xvi). 1-3: scale 1:2; 4-5: scale 1:3. 
concern the first stage of the Atlantic Early Iron Age (Milcent 2012, 142-67), and occasionally what appears to be an intermediary stage (Milcent in press). Most of the relative chronology work in this domain has yet to be carried out, and we hope that the dendrodates will lead one day to the establishment of an independent absolute chronology, i.e., that is not dependent on comparisons with the typo-chronologies and absolute dates obtained for the other cultures of the European Early Iron Age.

As for material culture affinities, the very marked recorded differences observed from one region to another in Atlantic Gaul in terms of the intensity and quality of excavations and publications are of considerable weight. One only has to compare Champagne with a vast region such as Pays-de-la-Loire for which practically no archaeological data have been published. Nonetheless, some indicators and information mark out the way: for the Atlantic Early Iron Age 1 (800-625 BC), individual inhumation below a tumulus is a virtually unknown funerary practice in northwestern Gaul, whereas it is predominant at the same time in the western Hallstattian domain. Generally speaking, tombs are rare, which points to the generalised use of funerary practices leaving few or no material traces, like for the Atlantic Late Bronze Age. The exception to this is what Eugène Warmenbol called the Mosan group, a culture with strong Atlantic affinities, with a rather original and mixed aspect, with tombs under tumuli, at times with a long pistiliform sword in bronze or iron. In spite of the adoption of the tumulus, the Mosan group practices in elitist tombs remain different to those found in west Hallstatt cultures as cremation is exclusive, sometimes concerns several deceased at a time and is generally accompanied by a 'defunctionalisation' of the sword in that it is broken and burnt (Warmenbol 1993). In several of these cremations, a reduced drinking service was found (three recipients at the most: Reinhard 1993), but this does not enable us to establish close links with elitist cremation tombs with swords from the central and eastern Hallstattian domains, as the latter contain sets of tableware, for both eating and drinking.

On another scale, reference should be made to the links that seem to bind the north of Gaul to the British Isles, judging by the distribution of the earliest variants of the pistiliform swords from the Gündlingen group (Milcent 2004, fig. 57-58; 2009, fig. 11). We also observe the persistence of tenuous contacts with the southwest of the Iberian Peninsula, in the form of locally produced objects during the 7th century $\mathrm{BC}$, but bearing for the first time decoration inspired by Syrian-Cypriot toreutics and Phoenician religious symbolism (hand-amulet depicting the heavenly goddess Tanit; Fig. 7.5, nos 1-3). Prototypes of these decorations are depicted on objects brought from the southwest of Spain and Portugal at the end of the Late Bronze Age by Phoenicians, then imitated on site (Fig. 7.5, nos 4-5). This implies that the long distance Atlantic contacts towards the southwest were not broken, even if they no longer attained the same intensity as during the Atlantic Late Bronze Age 2 and 3 early (1140-900 BC);
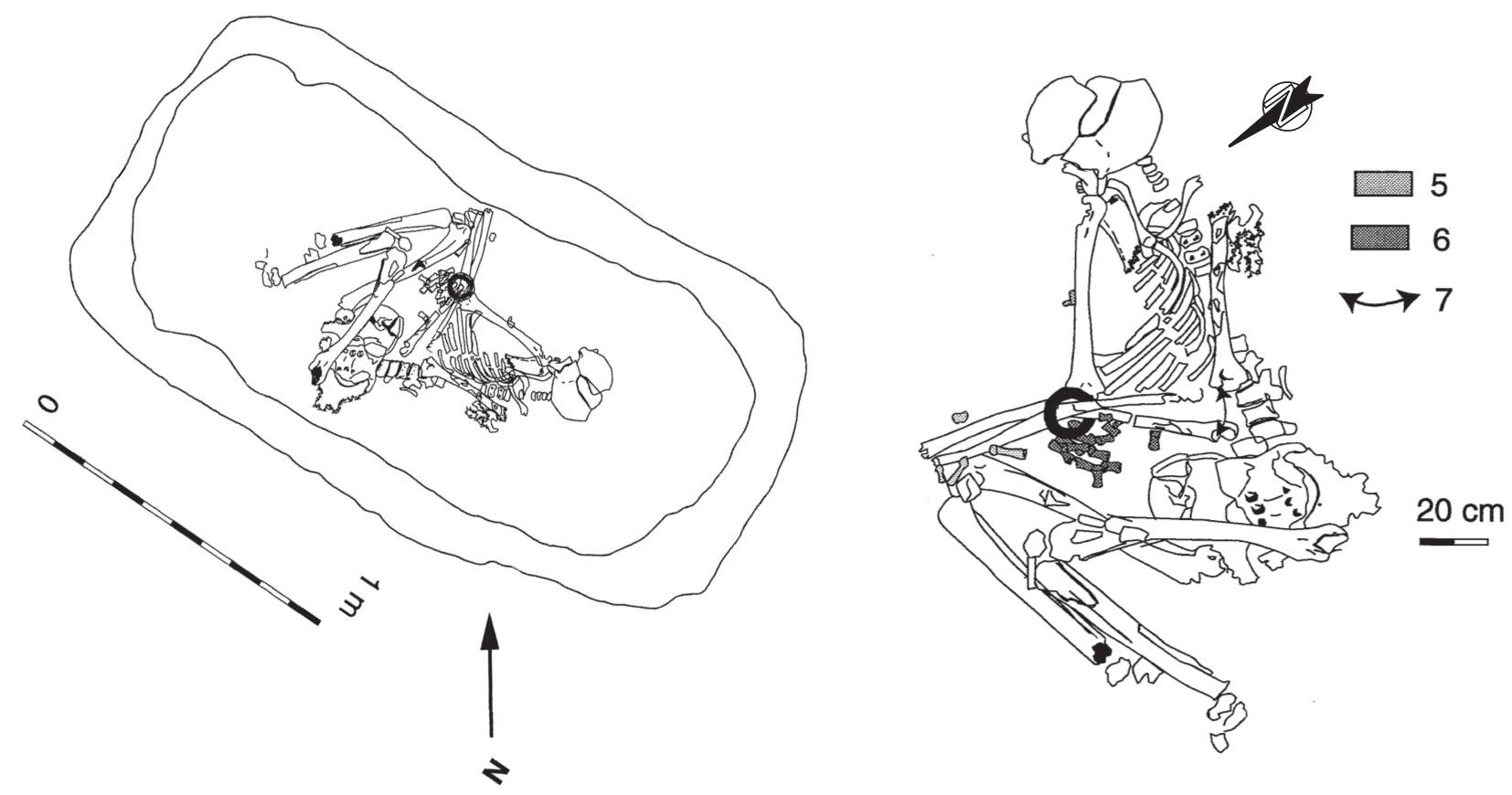

Fig. 7.6. Example of an inhumation placed on its side, with lower limbs flexed, in a large rectangular pit: Basly (Calvados, Normandy) tomb F7 (beginning 6th century BC) (after San Juan and Le Goff 2003). The grave was set in a square enclosure (cf Fig. $7.3 n^{\circ} 5$ ). 
during the Atlantic Early Iron Age 2 (625-525 BC), we note the exceptional development of the fabrication of pseudoaxes with sockets and massive hoards of these objects, but this phenomenon is hardly any different to the Armorican Massif, although it sporadically affects regions as far away as Picardy, Beauce and Touraine.

We will not describe in detail the original phenomenon observed from Brittany to Champagne to Pas-de-Calais, with what appears to be the abrupt development of inhumation burials in a deep rectangular pit, and not directly on the ground below a tumulus. Buried individuals are placed in a lateral position, generally on their right side, with the legs bent, and the head towards the south or southeast (Fig. 7.6).

This phenomenon is also reflected in other regions in the extreme west of Europe, perhaps in England and peculiarly in the southwest of Portugal where burials in a lateral bent position (mostly on the right side) were recently discovered in rectangular pits, at times delimited by a quadrangular earthwork enclosure (Arruda et al. in press). But, if we return to Atlantic Gaul, it is true that a significant deficit of burials remains observable for this stage in most regions, pointing to the widespread use of funerary practices leaving no archaeological trace. On a very wide scale, the diffusion of small or large cup mark decorations on pottery extends overs a vast Atlantic area. These decorations persist during the following stage (Milcent 2006, map fig. 6); at the end of the Early Iron Age and the beginning of the following period (525-425 BC), the most remarkable phenomenon is the generalisation of the production of hand-made pottery with angular profiles, while these forms remain practically unknown in the Hallstattian domain.

The multiplication of settlement excavations in the west of France reveals that very comparable productions extend

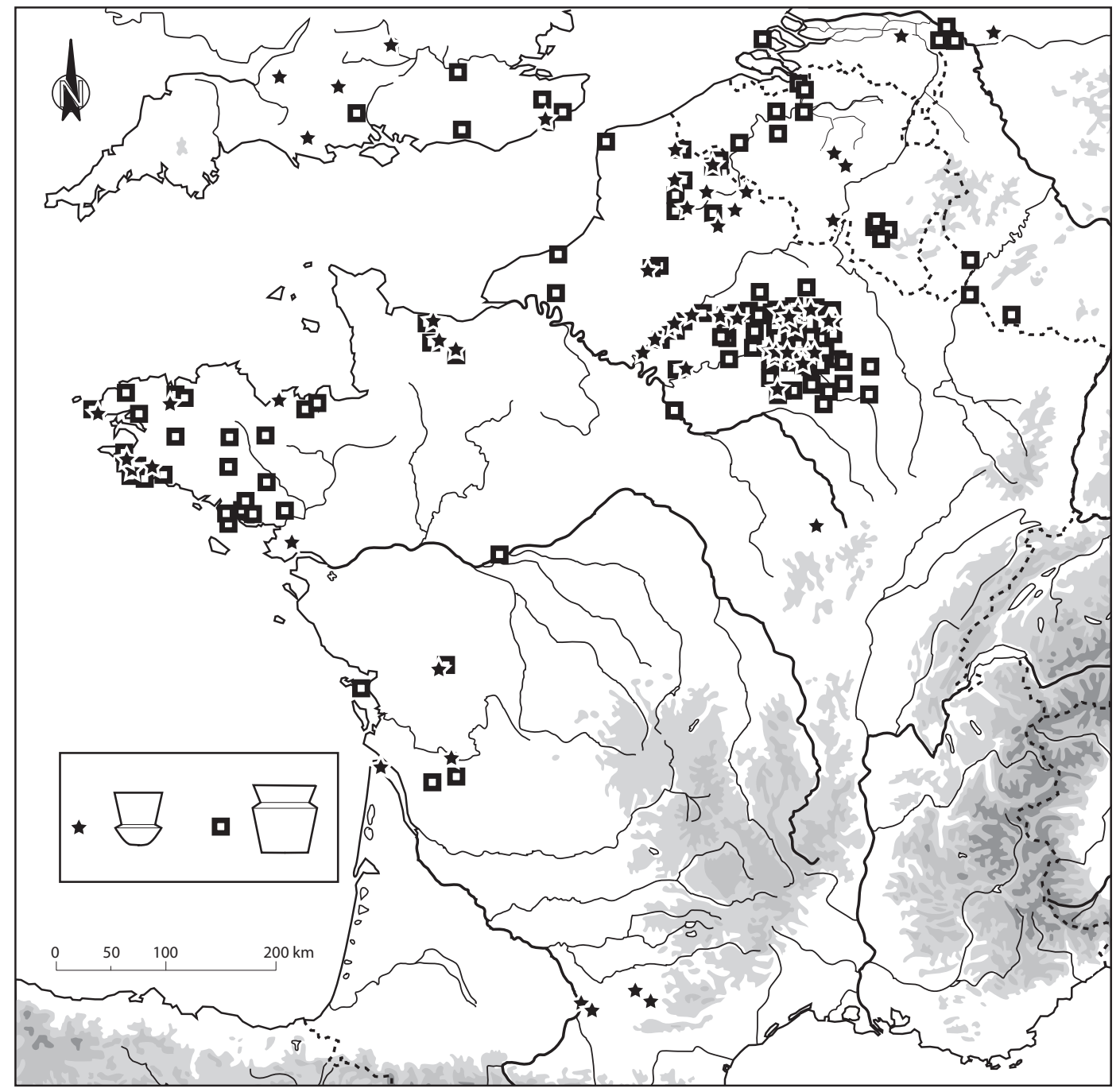

Fig. 7.7. Distribution map of two forms of medio-Atlantic carinated pottery from the late 6th-5th century BC (after Milcent 2006, Fig. 4). 
from Flanders to Vendée, right through Normandy and Brittany (Fig. 7.7), whereas until recently these productions appeared to be limited to Champagne and the neighbouring regions. Prototypes of these forms (low carinated goblets and high carinated pots) were known from the beginning of the 6th century BC in western Languedoc (see for example the $\mathrm{C}$ family vases from the Castrais necropolis classification: Giraud et al. 2003, vol. 1, fig. 40-41).

During the 5th century BC, several regional groups from the south of England participate in the regional production area of these angular carinated vases, but in lesser proportions. The distribution map for what we can call truly Medio-Atlantic pottery largely overlaps with that of a new clothing fashion, materialized by the diffusion of filiform fibulae with a raised foot and ending in a widened appendage during the course of the 5th century BC (Fig. 7.8). We observe that these fibulae with short springs are the first to be undeniably produced on site as they have practically no equivalent in west Hallstattian regions where the fibula with an drum foot and crossbow spring are largely dominant (Milcent 2004, 245, fig. 106). On the other hand, they are clearly affiliated to the Gulf of Lion type IberianLanguedoc productions with prototypes going back until at least the beginning of the 6th century BC. Once again, they demonstrate that the contacts established with regions in the southwest of Europe were not necessarily less significant than those established with the Hallstattian world.

Lastly, the use of funerary practices with archaeologically materialized tombs appears to intensify. Whereas burials are predominant in the north of Atlantic Gaul and appear to develop in the south of England, ${ }^{2}$ conversely cremation appears to prevail in the west, particularly in the Armorican Massif. This latter aspect may not be unrelated to the extension of cremation in southern Gaul throughout the

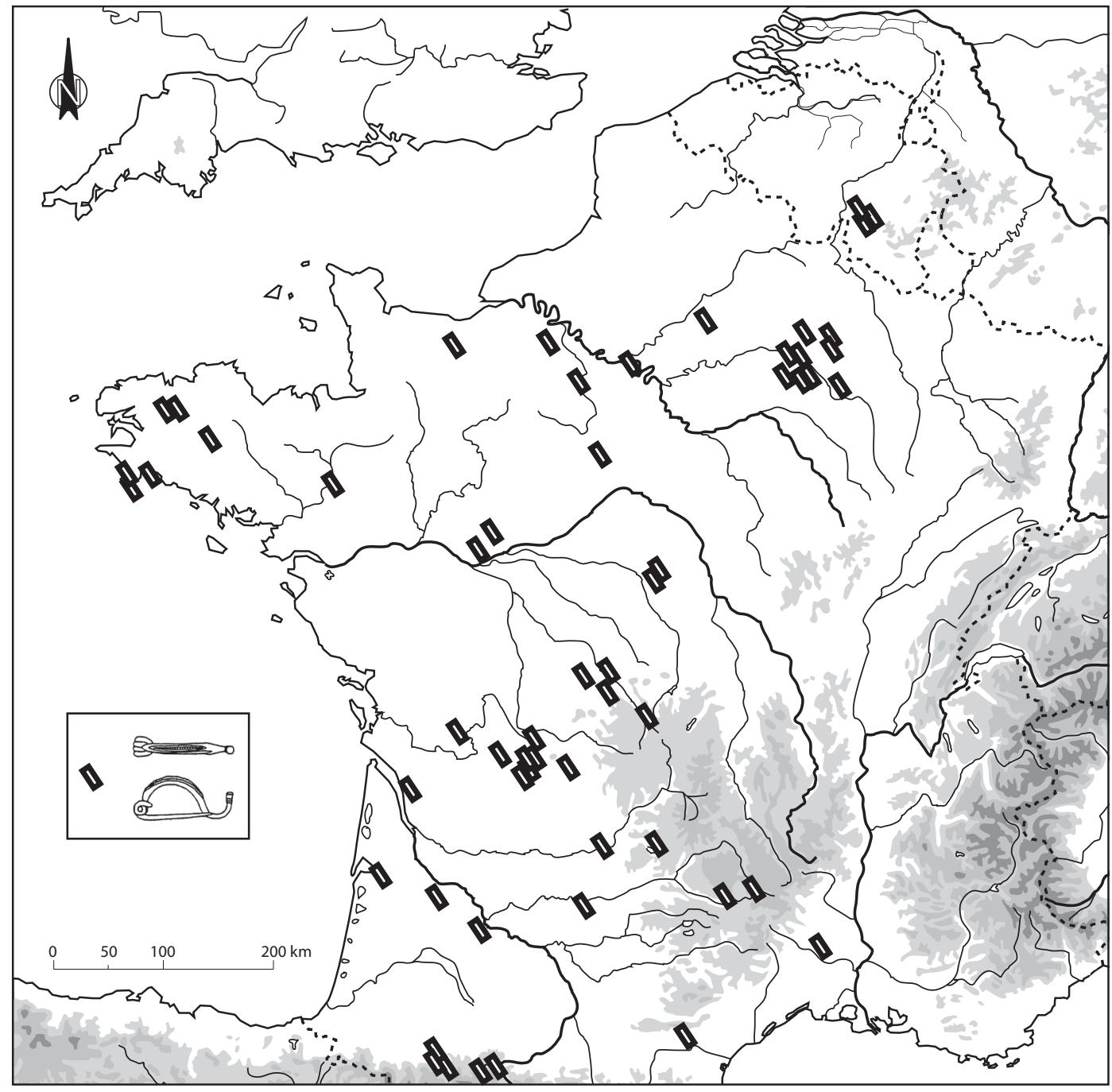

Fig. 7.8. Distribution map of brooches with upright foot and spring of La Tène style of the 5th century BC (after Milcent 2006, Fig. 10). Southern England and Western Germany are not mapped. 
Early Iron Age (Dedet 2004), by means of specific practices denoting an adaptation to distinct cultural contexts. As for the contacts established beyond the Channel, it is interesting to note that burials with non-dismantled twowheeled chariots from the 5 th century BC are now known in Yorkshire and the southeast of Scotland (Boyle 2004; Carter et al. 2010), which could provide evidence of affinities with Champagne. On the Continent and in the northwest, these 5 th century chariot tombs are not confined to Champagne, as they are also known in the Belgian Ardennes, the south of Holland, in Brittany and Charente-Périgord. The first well-dated burials in lateral position with bent lower limbs
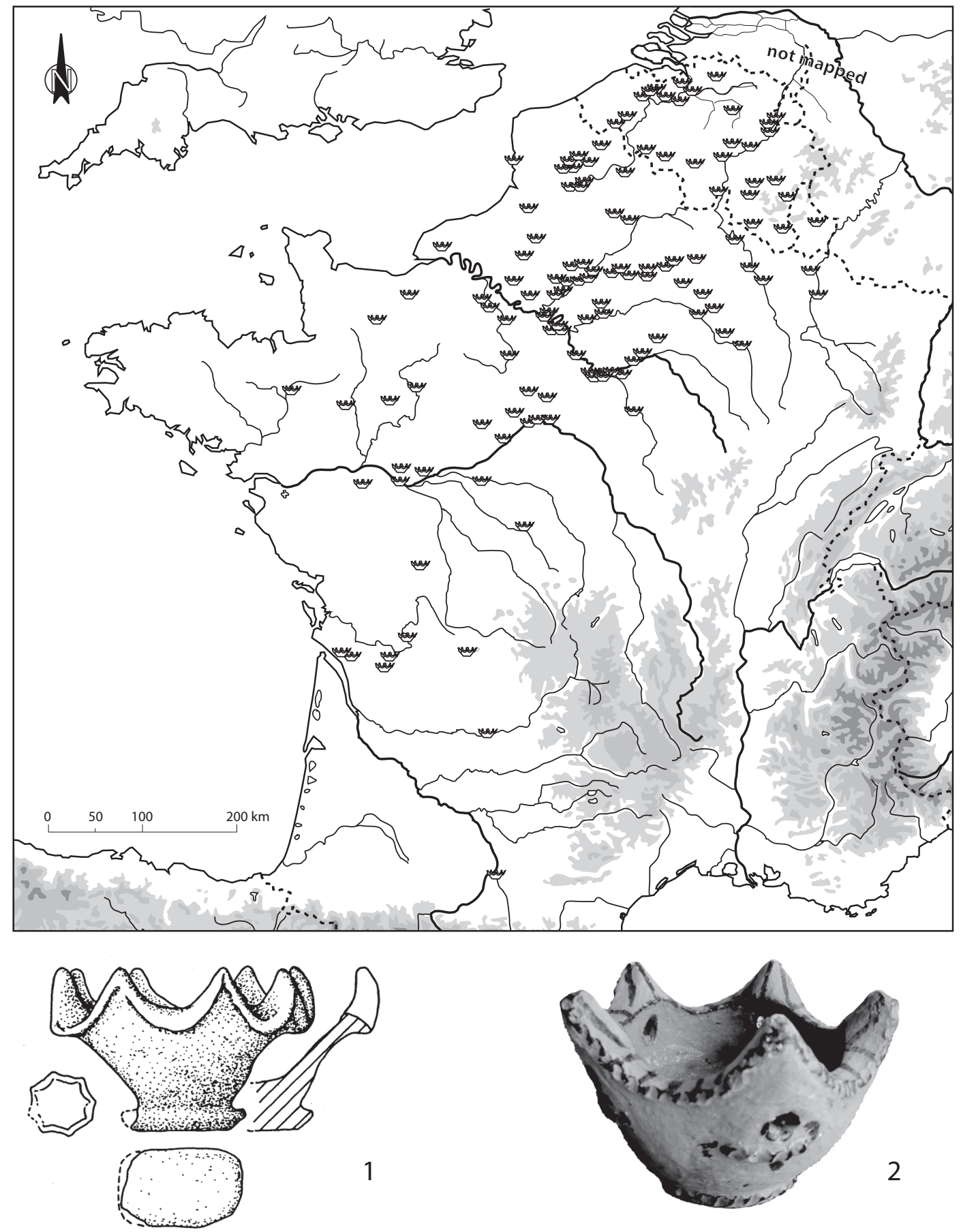

Fig. 7.9. Distribution of 'cups' with scalloped edges and a drawing of an example from Epraves in Belgium (1). For comparison, a Kanoun (cooking brazier) from the Maghreb (2). 
in Yorkshire are also attributed to this period. As we have already seen, this funerary ritual is well documented several decades earlier in the north of Gaul and we can question whether certain Yorkshire tombs without objects might not be older but rather contemporaneous with their continental counterparts.

In a more diachronic perspective, let us mention the very particular form of vessel, the large bowl with festooned edges, known from the beginning of the Iron Age in northern Gaul, and which spreads to the whole west of Gaul, apart from Armorica, at the beginning of the Late Iron Age (Fig. 7.9). This distribution almost completely disregards the Hallstattian world. It undoubtedly signifies a form of cultural community if we admit that this utensil was used for a specific culinary practice: these festooned recipients may not be lamps, but brazier pots for embers used to cook food slowly in a pot placed above them, in the same way as the present-day kanouns in the Maghreb (Fig. 7.9, nos 1-2).

As far as settlement is concerned, let us recall that 'circular' houses are now known everywhere throughout Atlantic Gaul, although they are not very frequent. It is important to underline that these buildings with very British affinities appear several times in an enclosed settlement
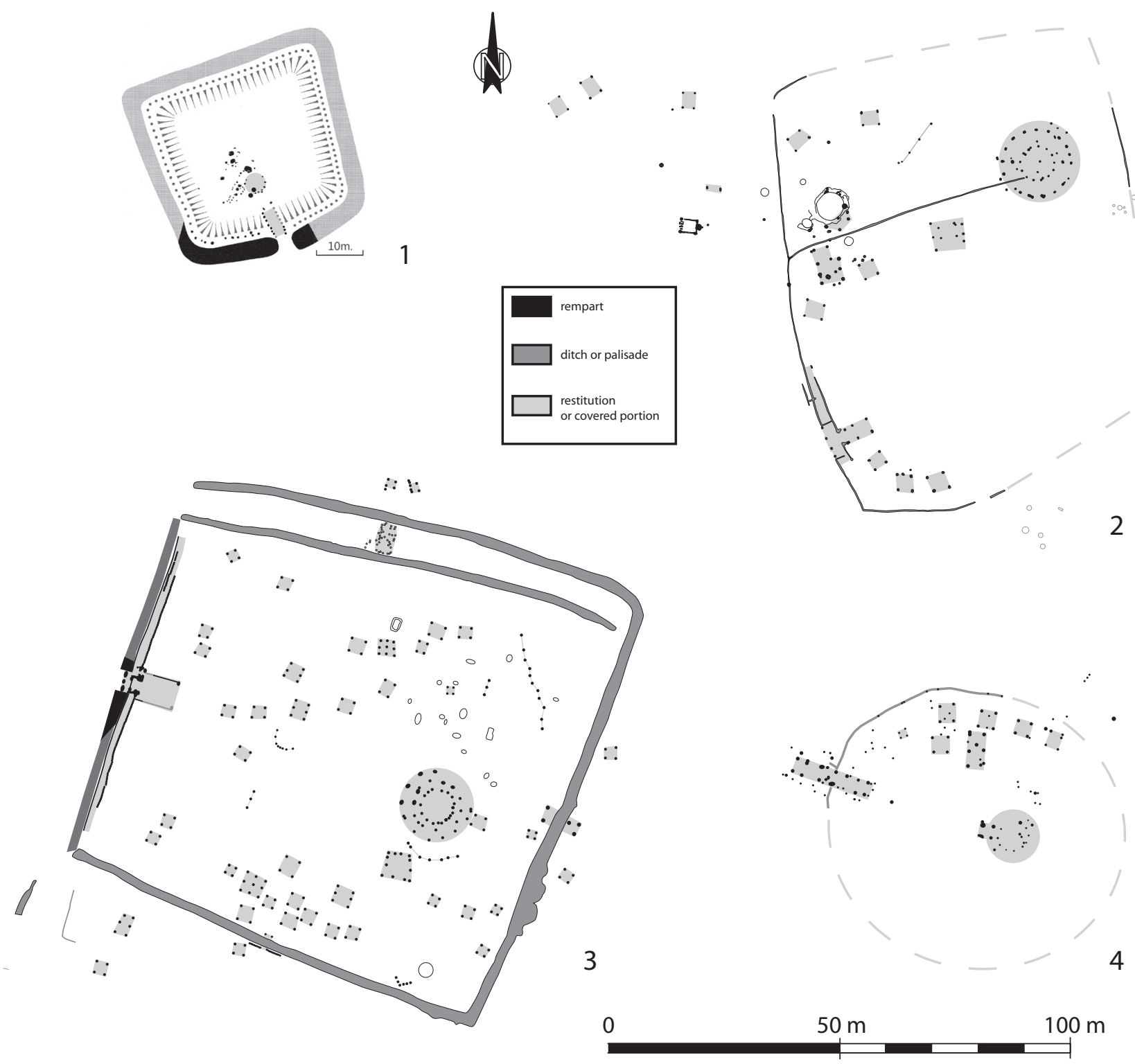

Fig. 7.10. The Late Bronze Age enclosure at Highstead in Kent for comparison (Clark 2012), and examples of ditched and/or palisaded farmsteads of the Early Iron Age, with round house in Atlantic Gaul. 2: Bezannes (Marne) 'La Bergerie' (after Desbrosse et al 2012, modified); 3: Courseulles-sur-Mer (Calvados) 'La Fosse Touzé' (after Jahier 2011, modified); 4: Méaulte (Somme) 'ZAC du pays des Coquelicots' (after Buchez 2012, modified). 
context, with an elitist vocation or appearance, throughout the Early Iron Age (Fig. 7.10, nos 2-4). Although they are not common, this typically Atlantic architectural model appears to be socially valued and seems to be used at times as a strong identity marker.
In the same way, and in spite of the fact that we could be tempted to establish connections with the 'Herrenhöfe' from the Bavarian Early Iron Age, it is increasingly clear that large centres of agro-pastoral domains with ditched or quadrilateral palisaded enclosures emerge at an early stage in the Atlantic

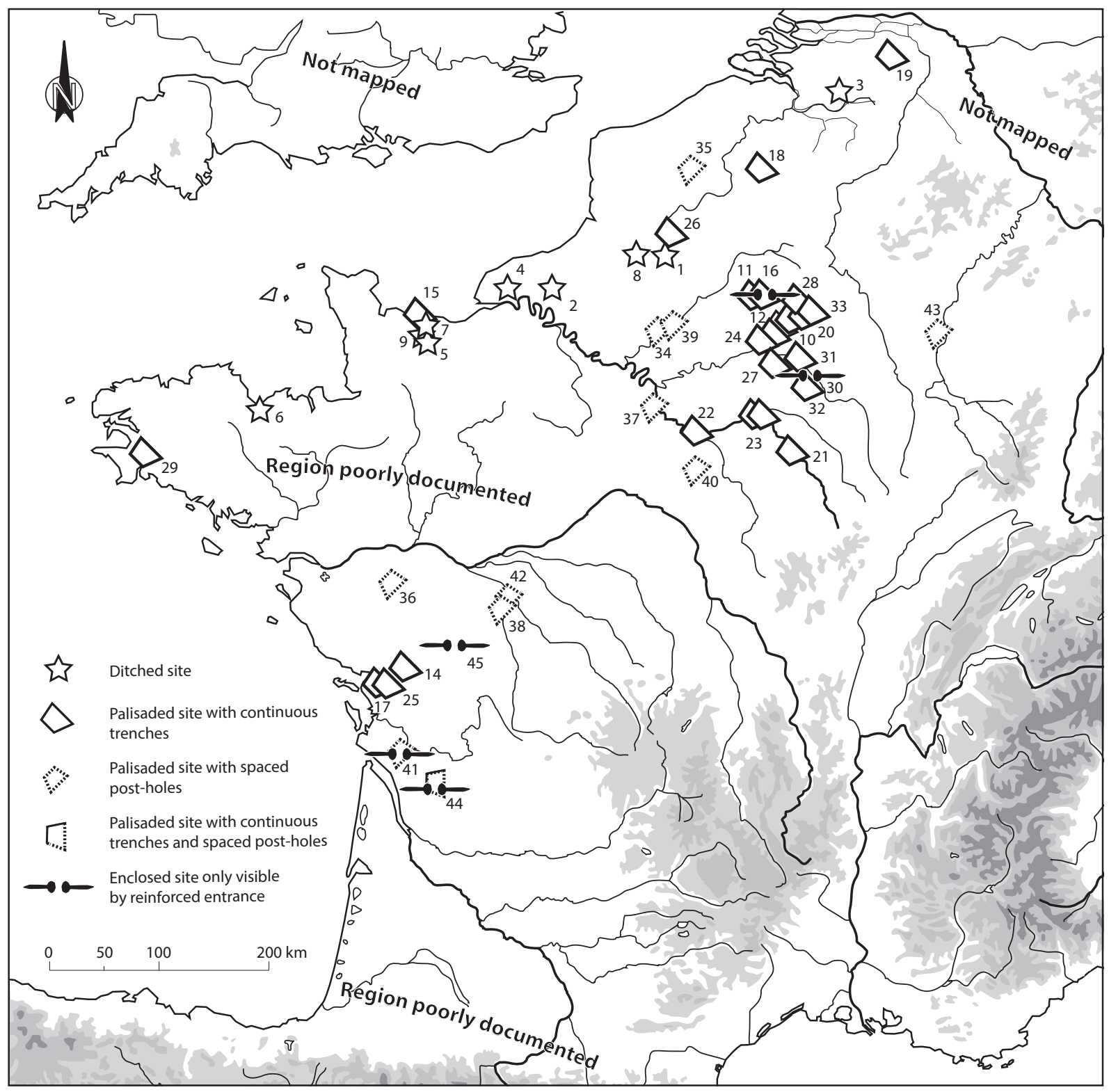

Fig. 7.11. Distribution of enclosed agricultural sites and farmsteads dating from the end of the Bronze Age to the middle Early Iron Age (10th-mid-6th centuries BC) in Atlantic Gaul. The scarcity of palisaded sites to the west of the Paris Basin is explained by bias rather than cultural or historical reality. Ditched sites: Amiens (1); Beautot (2); Beerse (3); Epretot (4) ; Fontenay-le-Marmion (5); Lamballe (6); Mathieu (7); Pont-de-Metz (8); Saint-Martin-de-Fontenay (9). Sites with palisades based on continuous trenches : Bazancourt (10); Beaurieux (11); Bezannes (12); Coulon (14); Courseullessur-Mer (15); Cuiry-lès-Chaudardes (16); Dompierre-sur-Mer (17); Ghislenghien (18); Gemert Bakel (19); Isles-sur-Suippe (20); La Chapelle-Saint-Luc (21); La Grande-Paroisse (22); La Saulsotte (23); Les Mesneux (24); Longèves (25); Méaulte (26); Oger (27); Pomacle (28); Quimper (29); Saint-Germain-la-Ville (30); Saint-Gibrien (31); SaintMartin-sur-le-Pré (32); Warmeriville (33). Sites with palisades based on spaced post-holes : Boran-sur-Oise (34); Brebières (35); Cholet (36); Cesson (37); Ingrandes-sur-Vienne (38); Ponpoint (39); Préfontaines (40); Préguillac (41); Pussigny (42); Woippy (43). Sites with mixed palisade types (based on trenches and spaced post-holes: Barbezieux (44). Sites with enclosure visible only by reinforced entrance : Barbezieux (44); Chasseneuil-du-Poitou (45); Cuiry-lès-Chaudardes (16); Préguillac (41); Saint-Germain-la-Ville (30). 
arc of Gaul. They appear from the end of the Late Bronze Age or the very beginning of the Early Iron Age, which is to say clearly before their west Hallstattian counterparts and at the same time as their Bavarian counterparts. Furthermore, they are part of an earlier tradition that appeared during the Atlantic Middle Bronze Age and is well evidenced during the Late Bronze Age in the south-east of England, then sporadically in the north of France (palisaded circular enclosures of Brebières, Saint-Martin-sur-le-Pré in Marne and Ghislenghien in Hainaut). Mapping of the earliest sites, before the end of the 6th century BC shows a clear concentration in the north and the west of Gaul, in spite of the disparities due to the unequal development of rescue archaeology (Fig. 7.11). During the 5th century BC, these enclosed establishments remain much more frequent in Atlantic Gaul than in continental Gaul, probably pointing once again to a rather distinctive trait of Atlantic settlement.

Ultimately, and paradoxically, the evidence for characterising an Atlantic cultural entity appears to be more diversified during the Early Iron Age than during the Late Bronze Age, for which the identification of Atlantic cultures is mainly based on bronze productions and metallic hoards. This Atlantic Gaul during the Early Iron Age is also made up of a mosaic of cultures and maintains rather clear links with the southeast of England. All of these regions, from Yorkshire to Charente, are in a pivotal Medio-Atlantic area, within a network of more extensive links. However, in the absence of more substantial archaeological evidence, the contours of these networks have yet to be defined, particularly towards the south.

\section{Conclusion}

The notion of the Atlantic Early Iron Age is valid as it provides an explanatory framework for the analysis of remains contrasting with the material remains discovered in Hallstattian and southern Gaul, mainly on account of their early chronology or original characteristics. The discovery of large palisaded agro-pastoral domains in the western centre region, the multiplication of the discoveries of those enclosed by a ditch in Brittany and Normandy, their rarity in the eastern centre region and in the east, consolidate a predictive model outlined several years ago (Milcent 2006, 97-8).

In a traditional perspective centred on the Mediterranean and the Hallstattian world, Atlantic Gaul could be perceived as peripheral during the Early Iron Age, but this was certainly not the case judging for example by its important contribution to the genesis of Latenian material cultures. It could also appear to be conservative in certain respects. Effectively, the rupture with the Late Bronze Age appears to be less clear than in the Continental domain: non-funerary metallic hoard practices are still well represented, at least during the 7th-6th centuries BC. In the same way, unlike in the western and central Hallstattian world, we do not observe a process of increasing socio-economic complexity that would lead to more developed centralisation: princely tombs remain exceptional and are dispersed throughout areas with strong cultural mixing; there is no evidence of proto-urban agglomerations and no traces of trade with the Mediterranean, even though Mediterranean imports come in sporadically. In other words, in terms of socio-economic organization, the Medio-Atlantic societies of the Early Iron Age appear to be less complex and less hierarchical than elsewhere. But they also appear to be more stable and less prone to fluctuations than their eastern or southern counterparts. And they were perhaps more solidly organised than elsewhere. All this explains that the transition from the Early to the Late Iron Age also seems to be more gradual in the Medio-Atlantic domain than elsewhere.

To extend this reflection, the concept of the Early Iron Age resonates singularly well with the ethnical situation described in Gaul just before the Roman invasions (Milcent 2012,23). According to Caesar, the celtic speaking populations of the most northern and north-western regions of Gaul were respectively designated as Belgian and Armorican (Julius Caesar, B. G., I, 1; V, 53 and VII, 75), while certain earlier authors (Posidonius?), reiterated by Strabo (Géogr., IV, 1-4), describe all the populations located near the Atlantic and the Channel, between Gironde and the mouths of the Rhine as Belgian.

These associations raise questions as to the existence of an Atlantic Late Iron Age on one hand, which cannot be ruled out, and the hypothesis of a form of long-term ethnic identity stability on the other.

To conclude, the Atlantic Early Iron Age is also fundamental as it is a way of no longer focusing, like in the past, on the Mediterranean or the Hallstattian world, and thus of adopting a new approach to the European Early Iron Age. It is an indispensable intellectual lever for assessing the history of this period in a different, more dynamic and multipolar way. It is, in particular, an essential concept for bringing to light the multiplicity and the 'international' aspect of the networks that gave rise to the emergence of the material La Tène cultures. In this paper, there is no question of replacing centre-periphery models that have served their time by 'Atlantico-centric' models. From this point of view, the position adopted here is different to recent work by B. Cunliffe (2010), arguing for an Atlantic origin for the Celts, as these new hypotheses only inverse existing perspectives without really changing the more problematic foundations.

\footnotetext{
Notes

1 It would be appropriate to reexamine the detailed study of the elements found in Champagne assimilated to red Mediterranean coral. Indeed, recent research shows that substitutes, bone in particular, could have been used instead of real Mediterranean coral.
} 
2 Here, we refer to the oldest known pit burials in Yorkshire and Cornwall (Harlyn Bay), with associated metallic objects going back to the 6th-5th century $\mathrm{BC}$, although our British colleagues often advocate short chronologies out of step with the Continent.

\section{Bibliography}

Arruda, A., Barbosa, R., Gomes, F. B. and Sousa, A. (in press) A necropolis da Vinha das Caliças 4. Sidereum III. Madrid, El Rio Guadiana en Epoca Tartésica.

Berranger, M. (2014) Le fer, entre matière première et moyen d'échange, en France, du VIIe au Ier siècle avant J.-C. Approches interdisciplinaires. Dijon, Editions Universitaires de Dijon.

Blanchet, J.-C. (1984) Les premiers métallurgistes en Picardie et dans le nord de la France. Paris, Mémoires de la Société préhistorique française 17.

Blanchet, J.-C. and Talon, M. (2005) L'âge du Bronze dans la moyenne vallée de l'Oise: apports récents. In J. Bourgeois et M. Talon (eds) L'âge du Bronze du nord de la France dans son contexte européen, $125^{\mathrm{e}}$ congrès de CTHS, Lille 2000, 227-268. Paris, CTHS-APRAB.

Boyle, A. (2004) The Ferrybridge chariot burial. Current Archaeology 191, 481-5.

Briard, J. (1965) Les dépôts bretons et l'Âge du bronze atlantique. Rennes, Thèse de Sciences naturelles.

Brun, P. (1987) Princes et princesses de la Celtique. Le premier age du Fer en Europe 850-450 av. J.-C. Paris, Errance.

Buchez, N. (2012) La ferme de Méaulte (Somme). In A. Lehoërff (ed.) Par-delà l'horizon. Sociétés en manche et mer du Nord il y a 3500 ans, 121-2. Paris, Somogy Editions d'Art.

Cabboi, S., Dunikowski, C., Leroy, M. and Merluzzo, P. (2007) Les systèmes de production sidérurgique chez les Celtes du Nord de la France. In P.-Y. Milcent (ed.) L'économie du fer protohistorique: de la production à la consommation du métal. Actes du XXVIII colloque international de l'AFEAF, Toulouse 20-23 mai 2004, 35-62. Bordeaux, Aquitania, supplément 14/2.

Carter, S., Hunter, F. and Smith A. (2010) A 5th Century BC Iron Age Chariot Burial from Newbridge, Edinburgh. Proceedings of the Prehistoric Society 76, 31-74.

Clark, P. (2012) Highstead: un fort de l'âge du Bronze? In A. Lehoërff (ed.) Par-delà l'horizon. Sociétés en manche et mer du Nord il y a 3500 ans. 125. Paris, Somogy Editions d'Art.

Collard, M., T. Darvill, M. Watts M. (2006) Ironworking in the Bronze Age? Evidence from a 10th century BC Settlement at Hartshill Copse, Upper Buckelbury, West Berkshire. Proceedings of the Prehistoric Society, 72, p.367-422

Collis, J. (1986) Adieu Hallstatt! Adieu La Tène! In A. Duval and J. Gomez (eds) Actes du VIIIe colloque sur les Âges du Fer en France non méditerranéenne, Angoulême, 18-19-20 mai 1984, 327-30. Bordeaux, Aquitania, supplément 1.

Cunliffe, B. (2010) Celticization from the west: The contribution of archaeology. In B. Cunliffe and J. T. Koch (eds) Celtic from the West. Alternative Perspectives from Archaeology, Genetics, Language and Literature. 13-38. Oxford, Oxbow Books.

Déchelette, J. (1913) [1927] Manuel d'archéologie préhistorique, celtique et gallo-romaine. III, Premier âge du fer ou époque de Hallstatt. Paris, Picard.
Dechezleprêtre, T. and Ginoux, N. (2005) Les constructions circulaires de la moitié nord de la France: état de la question. In O. Buchsenschutz and Cl. Mordant (eds) Architectures protohistoriques en Europe occidentale du Néolithique final à l'âge du Fer. Actes du 127e congrès des Sociétés historiques et scientifiques, Nancy 2002, 77-87. Paris, Editions du Comité des Travaux historiques et scientifiques.

Dedet, B. (2004) Variabilité des pratiques funéraires protohistoriques dans le sud de la France: défunts incinérés, défunts non brûlés. Gallia 61, 193-222.

Dehn, W. and Stöllner, T. (1996) Fußpaukenfibel und Drahtfibel (Marzabottofibel) - ein Beitrag zum kulturhistorischen Verständnis des 5. Jh. in Mitteleuropa. In T. Stöllner (ed.) Europa celtica. Untersuchungen zur Hallstatt- und Latènekultur, 1-54. Espelkamp, Marie Leidorf.

De Laet, J., Thoen, S. and Bourgeois J. (1986) Les fouilles du séminaire d'archéologie de la Rijksuniversiteit te Gent à Destelbergen-Eenbeekeinde (1960-1984) et l'histoire la plus ancienne de la région de Gent (Gand) I La période préhistorique. Dissertationes Archaeologicae Gandenses XXIII. Brugge, De Tempel.

Demoule, J.-P. (1999) Chronologie et société dans les nécropoles celtiques de la culture Aisne-Marne du VIème au III ${ }^{\text {İme }}$ siècle avant notre ère. Revue archéologique de Picardie spécial 15, Amiens, The Revue Archéologique de Picardie.

Desbrosse, V., Riquier, V. avec la collaboration de Bocquillon, H., Brun, O. and Kasprzyk, M. (2012) Les établissements ruraux palissadés hallstattiens en Champagne. In M. Schönfelder and S. Sievers (eds) L'âge du Fer entre la Champagne et la vallée du Rhin/Die Eisenzeit zwischen Champagne und Rheintal, Actes du XXXIVe colloque international de l'A. F. E. A. F., Aschaffenburg 2010, 3-27, Tagungen Band 14. Mainz, Römisch-Germanisches Zentralmuseum.

Gerloff, S. (2010) Atlantic Cauldrons and Buckets of the Late Bronze and Early Iron Ages in Western Europe. Prähistorisches Bronzefunde II, 18, Stuttgart Frank Steiner.

Giot, P.-R. (1950) Remarques préliminaires sur la chronologie de la fin de l'Âge du Bronze et sur celle de l'Âge du Fer en Bretagne. Bulletin de la Société préhistorique française t. 47, 336-340.

Giot, P.-R., Briard, J. and Pape, L. (1979) Protohistoire de la Bretagne. Rennes, Ouest-France Université.

Giraud, J.-P., Pons, F., Janin, T. (ed.), avec la collaboration de Carozza, J.-M., Duday, H., Forest, V., Gardeisen, A., Lagarrigue, A. and Roger, J. (2003) Nécropoles protohistoriques de la région de Castres (Tarn). Le Causse, Gourjade, Le Martinet. Documents d'Archéologie Française 94. Paris, Éditions de la Maison des sciences de l'Homme.

Gomez de Soto, J. and Kerouanton, I. (2009) Les premiers objets en fer en France, à l'âge du Bronze. In M.-J. Roulière-Lambert, A. Daubigney, P.-Y. Milcent, M. Talon and J. Vital (dir.) De l'âge du Bronze à l'âge du Fer en France et en Europe occidentale (Xe-VIIe s. av. J.-C.). La moyenne vallée du Rhône aux âges du Fer. Actes du $\mathrm{XXX}^{\mathrm{e}}$ colloque international de l'AFEAF, co-organisé avec l'APRAB (Saint-Romain-en-Gal, 26-28 mai 2006), 501-6. Dijon, supplément 27 à la Revue archéologique de l'Est.

Gomez de Soto, J., Bourhis, J.-R., Ghesquiere, E., Marcigny, C., Ménez, Y., Rivallain, J. and Verron, G. (2009) Pour en finir avec le Bronze final ? Les haches à douille de type amoricain 
en France. In M.-J. Roulière-Lambert, A. Daubigney, P.-Y. Milcent, M. Talon and J. Vital (eds) De l'âge du Bronze à l'âge du Fer en France et en Europe occidentale (Xe-VIIe s. av. J.-C.). La moyenne vallée du Rhône aux âges $d u$ Fer. Actes du $\mathrm{XXX}^{\mathrm{e}}$ colloque international de l'AFEAF, co-organisé avec l'APRAB (Saint-Romain-en-Gal, 26-28 mai 2006), 507-12. Dijon, supplément 27 à la Revue archéologique de l'Est.

Guggisberg, M. A. (2004) (ed.) Die Hydria von Grächwil. Zur Funktion und Rezeption mediterraner Importe in Mitteleuropa im 6. und 5. Jahrhundert v. Chr., Actes du colloque de Bern. Berne, Schriften des Bernischen Historischen Museums.

Harding, D. W. (1972) The Iron Age in the Upper Thames Basin. Oxford, Clarendon Press.

Haselgrove, C. (2007) Rethinking earlier Iron Age settlement in the eastern Paris Basin. In C. Haselgrove and R. Pope (eds) The Earlier Iron Age in Britain and the Near Continent, 400-428. Oxford, Oxbow Books.

Hatt, J.-J. and Roualet, P. (1976) Le cimetière des Jogasses en Champagne et les origines de la civilisation de La Tène. Dijon, Revue archéologique de l'Est t. 27, 421-448.

Hatt, J.-J. and Roualet, P. (1977) La chronologie de la Tène en Champagne. Dijon. Revue archéologique de l'Est t. 28, 7-36.

Jahier, I. (2005) Eterville. Le Clos des Lilas. Bilan scientifique 2004, 39-41. Caen, S. R. A. BasseNormandie.

Jahier, I. (2011) L'enceinte des premier et second âge du Fer de La Fosse Touzé (Courseulles-sur-Mer, Calvados). Entre résidence aristocratique et place de collecte monumentale. Documents d'Archéologie Française 104. Paris, Editions de la Maison des Sciences de l'Homme.

Jiménez-Ávila, J. (2002) La Toréutica Orientalizante en la Península Ibérica. Bibliotheca Archaeologica Hispana 16, Studia hispano-phoenicia. Madrid, Real Academia de la Historia.

Joly, S., Mercey, Fl., Filippini, A., Abenzoar, V., Liard, M. et Poupon F. avec la collaboration de Béziat D. et Coustures M.-P. (2011) Un nouvel habitat du Bronze final IIIb dans le Val d'Orléans: Bonnée, « Les Terres à l'Est du Bourg » (Centre, Loiret), Revue archéologique du Centre de la France, [En ligne] t. 50.

Le Goff, I. and Guillot, H. (1992) Étude des ossements incinérés de la nécropole de l'Âge du bronze de Tagnon 'La Fricassée'. Amphora 73, 35-44.

Mariën, M.-E. (1958) Trouvailles du Champ d'Urnes et des tombelles hallstattiennes de Court-Saint-Etienne. Monographies d'Archéologie Nationale, 1. Bruxelles, Musées royaux d'Art et d'Histoire.

Ménez, Y. (1996) Une ferme de l'Armorique gauloise. La Boisanne à Plouër-sur-Rance (Côtes-d'Armor). Documents d'Archéologie Française 58. Paris, Editions de la Maison des Sciences de l'Homme.

Milcent, P.-Y. (2003) Le contexte historique. In C. Rolley (ed.) La tombe princière de Vix, 327-366. Paris, Picard.

Milcent, P.-Y. (2004) Le premier âge du Fer en France centrale. Paris, Mémoire de la Société préhistorique française t. XXXIV.

Milcent, P.-Y. (2006) Premier âge du Fer médio-atlantique et genèse multipolaire des cultures matérielles laténiennes. In D. Vitali (ed.) Celtes et Gaulois, l'archéologie face à l'Histoire, 2: la préhistoire des Celtes, Actes de la table ronde de BologneMonterenzio, 28-29 mai 2005, 81-105. Glux-en-Glenne, Bibracte 12/2.
Milcent, P.-Y. (2009) A l'Est rien de nouveau. Chronologie des armes de poing du premier âge du Fer médio-atlantique et genèse des standards matériels élitaires hallstattiens et laténiens. In A. Lehoërff (ed.) Construire le temps. Histoire et méthodes des chronologies et calendriers des derniers millénaires avant notre ère en Europe occidentale. Actes du XXXe colloque international HALMA-IPEL, Lille 7-9 décembre 2006, 231-250. Glux-en-Glenne, Bibracte 16.

Milcent, P.-Y. (2012) Le temps des élites en Gaule atlantique. Chronologie des mobiliers et rythmes de constitution des dépôts métalliques dans le contexte européen (XIIIe-VIIe s. av. J.-C.). Rennes, Presses Universitaires de Rennes, Archéologie \& culture.

Milcent, P.-Y. (2014) Hallstattian urban Experience before the Celtic Oppida in central and eastern Gaul. Two case studies: Bourges and Vix. In M. Fernández-Götz, H. Wendling and K. Winger (eds) Paths to Complexity - Centralisation and Urbanisation in Iron Age Europe, 35-51. Oxford, Oxbow Books.

Milcent, P.-Y. (2015) Bronze objects for Atlantic Elites in France (13th-8th century BC). In F. Hunter and I. Ralston (eds) Scotland in Later Prehistoric Europe, Actes de la conférence internationale d'Edimbourg, 19-21 septembre 2008, 19-46. Edinburgh, Society of Antiquaries of Scotland.

Milcent, P.-Y. (in press) Echanges prémonétaires et immobilisation fluctuante de richesses métalliques en Gaule atlantique (XIIIeVe s. av. J.-C.). Dynamiques et décryptage des pratiques de dépôts métalliques non funéraires. In B. Toune and E. Warmenbol (eds), Choice Pieces. The Destruction and Manipulation of Goods in the Later Bronze Age: From Reuse to Sacrifice. Actes du colloque de Rome 2012, Academia Belgica Rome, Academia Belgica.

Needham, S. (2007) 800 BC, The great divide. In C. Haselgrove and R. Pope (eds) The Earlier Iron Age in Britain and the Near Continent, 39-63. Oxford, Oxbow Books.

Pape, J. (2000) Die attische Keramik der Heuneburg und der keramische Südimport in der Zone nördlich der Alpen während der Hallstattzeit. In W. Kimmig (ed.) Importe und mediterrane Einflüsse auf der Heuneburg. Heuneburgstudien, XI, 71-175. Mainz am Rhein, P. von Zabern.

Reinhard, W. (1993) Gedanken zum Westhallstattkreis am Beispiel der Ha C - zeitlichen Schwertgräber. Blesa 1. 359-387. Metz, Éditions Serpenoise.

San Juan, G. and Le Goff, I. (2003) La nécropole du VI siècle avant J.-C. de 'La Campagne' à Basly (Calvados). In B. Mandy and A. De Saulce (eds) Les marges de l'Armorique à l'âge du Fer. Archéologie et histoire: culture matérielle et sources écrites, Actes du XXIIIe colloque de l'A. F. E. A. F., Nantes 1999, 59-102. Rennes, Revue archéologique de l'Ouest, supplement 10 .

Saurel, M. (2007) Les $\mathrm{IV}^{\mathrm{e}}$ et $\mathrm{III}^{\mathrm{e}}$ siècles avant notre ère en Champagne-Ardenne: apport de l'étude de la vaisselle des habitats. In Chr. Mennessier-Jouannet, A. Adam and P.-Y. Milcent (eds) La Gaule dans son contexte européen aux IVe et IIIe s. av. n. è. Actes du XXVIIe colloque international de l'AFEAF, Clermont-Ferrand, 29 mai-1er juin 2003, 7-33. Lattes, Monographies d'Archéologie Méditerranéenne.

Séjalon, P. and Dedet, B. (2003) Les trois enclos funéraires de Mas de Vignole VII à Nîmes, Gard (Ve s. av. J.-C.). Documents d'Archéologie méridionale 26, 43-61. 
Van Doorselaer, A., Putman, R., Van der Gucht, K. and Janssens, Fr. (1999) De Kemmelberg een Keltische bergvesting. Kortrijk, Westvlaamse Archaeologica Monografieën III.

Verger, S. (1995) De Vix à Weiskirchen. La transformation des rites funéraires aristocratiques en Gaule du nord et de l'est au Ve siècle avant J.-C. Mélanges de l'École française de Rome Antiquité 107, 1, 335-458.

Verney, A. (1993) Les nécropoles de l'âge du Fer en BasseNormandie; bilan de trois siècles de découvertes. In D. Cliquet, M. Rémy-Watté, M. Vaginay and V. Guichard (eds) Les Celtes en Normandie. Les rites funéraires en Gaule (IIIe-Ier siècle avant J.-C.), 95-113, Rennes, Revue archéologique de l'Ouest, Supplément 6.

Vilaça, R. (2013) L'arrivée des premiers fer dans l'Occident atlantique. In L. Callegarin and A. Gorgues (eds) Les transferts de technologie au premier millénaire av. J.-C. dans le sud-ouest de l'Europe, 39-64. Mélanges de la Casa de Velázquez, Madrid, Casa de Velázquez.

Villard-Le Tiec, A., Ménez, Y. and Lohro T. (2013) Habitats et nécropoles de l'âge du Fer en Centre-Bretagne. In S. Krausz,
A. Colin, K. Gruel, I. Ralston and T. Dechezleprêtre (eds) L'âge du Fer en Europe. Mélanges offerts à Olivier Buchsenschutz, 261-279. Bordeaux, Ausonius.

Villes, A. (2000) Entre principautés et chefferies, citadelles et fermes, le Hallstatt final en Champagne: données nouvelles. In A. Villes and A. Bataille-Melkon (eds) Fastes des Celtes entre Champagne et Bourgogne aux VIIe-IIIe siècles avant notre ère. Actes du 19e Colloque de l'A. F. E. A. F., Troyes 1995, 11-92. Chalon-en-Champagne, Mémoires de la Société archéologique champenoise 15.

Warmenbol, E. (1993) Les nécropoles à tombelles de Gedinne et Louette-Saint-Pierre (Namur) et le groupe 'mosan' des nécropoles à épées hallstattiennes. In F. Boura, J. Metzler and A. Miron (eds) Interactions culturelles et économiques aux Âges du Fer en Lorraine, Sarre et Luxembourg. Actes du XIe colloque de l'A. F. E. A. F., Sarreguemines 1987, 83-114. Metz Archaeologia Mosellana. 